\title{
Dimensões historiográficas da virada visual ou o que pode fazer o historiador quando faz histórias com imagens?
}

\begin{abstract}
Resumo
As imagens não são mais novidades na pesquisa historiográfica. Contudo, propostas no início dos anos 1990, a pictorial turn (nos EUA, por W. J. T. Mitchell) e a iconic turn (na Alemanha por Gottfried Boehm) alteraram o cenário das pesquisas interdisciplinares sobre artefatos visuais a partir de princípios da alteridade das imagens em relação à linguagem e da historicidade da cultura visual. Soma-se as essas propostas a anacronia das imagens e da sintomatologia de Georges Didi-Huberman, historiador da arte francesa. Este artigo procura avaliar o impacto historiográfico das viradas às imagens em dois aspectos fundamentais do trabalho do historiador: a produção de uma heurística da imagem e da fonte histórica; as construções do tempo/historicidade e da visibilidade do passado e seus usos públicos. Cruzando recursos da história da historiografia e da teoria da imagem e da história, o artigo apresenta em três seções: as matrizes norte-americana, alemã e francesa das viradas pictóricas/icônicas/visuais; as dimensões históricas e historiográficas das viradas; a concepção de fonte histórica, de temporalidade e o problema da visibilidade do passado na atualidade.
\end{abstract}

Palavras-chave: Cultura Visual. História da Historiografia. Anacronia e Historicidade. Virada Visual.

\author{
Francisco das Chagas Fernandes Santiago Júnior \\ Doutor em História pela Universidade Federal \\ Fluminense (UFF). Professor do Programa de Pós- \\ Graduação em História da Universidade Federal do \\ Rio Grande do Norte (UFRN). \\ Natal, RN - BRASIL \\ santiago.jr@gmail.com \\ orcid.org/0000-0003-2690-5222
}

\section{Para citar este artigo: \\ SANTIAGO JÚNIOR, Francisco das Chagas Fernandes. Dimensões historiográficas da virada visual ou o que pode fazer o historiador quando faz histórias com imagens? Tempo e Argumento, Florianópolis, v. 11, n. 28, p. 402 - 444, set./dez. 2019.}




\title{
Historiographic dimensions of the visual turn or what can do the historian when making histories with images?
}

\begin{abstract}
The images aren't new in historiographical research. However, proposals in the early 1990s, the pictorial turn (in the US by W. J. T. Mitchell) and the iconic turn (in Germany by Gottfried Boehm) altered the landscape of interdisciplinary research on visual artifacts through the principles of alterity of images in relation to the language and the historicity of visual culture. To them were added the anachronism of the images and the symptomatology of Georges Didi-Huberman, historian of French art. This text evaluates the historiographic impact of the images turns in two fundamental aspects of the work of historians: the production of an heuristic of the image as historical source; the constructions of time/historicity, visibility and public uses of the past. Crossing resources from the history of historiography and the theory of image and history, the article presents three sessions: the North American, German and French matrices of the pictorial/iconic/visual turns; the historical and historiographic dimensions of the visual turn; the conception of historical source, temporality and the problem of the visibility of the past in the contemporary world.
\end{abstract}

Keywords: Visual Culture. History of Historiography. Anachronism and Historicity. Visual Turn.

As imagens e metáforas estão muito presentes nos títulos e no corpo dos textos historiográficos. Contudo, se foi apenas com o giro linguístico que se consolidou a ideia de que a matéria-prima do escrever/dizer historiográfico (a linguagem) intervinha na "substância" do conhecimento histórico", o mesmo não pode ser dito sobre o reconhecimento do papel das imagens no fazer histórico e historiográfico. O terremoto que se seguiu a linguistic turn lançou a história em incertezas (CHARTIER, 1991), dividiu-a entre paradigmas (CARDOSO; VAINFAS, 1997), propôs a história como arte (ALBUQUERQUE JR., 2004), chamou-a de pós-moderna (ANKERSMIT, 2012), “terminou” por devolvê-la à cientificidade (RÜSEN, 2015). A disciplina passou por tantos giros/viradas

\footnotetext{
${ }^{1}$ Obras como Metahistory (WHITE, Hayden. Metahistory. Baltimore: John Hopkins University Press, 2014 original de 1973), Opération historiographique (CERTEAU, Michel de. A Escrita da História. 2 ed. Rio de Janeiro: Forense Universitária, 2002 - primeira versão de 1969), Comment on écrit l'histoire (VEYNE, Paul. Come si scrive la storia. Roma: Laterza, 1973 - original de 1972).
} 
quanto os pontos-de-vista puderam sustentar - cultural turn, historical turn, memorial turn e material turn. Por sua vez, os termos giro/virada e terremoto são metáforas e seu papel no discurso é gerar uma imagem. Também as imagens parecem conter uma nova virada, a qual, como tantas, corre o risco de cair no modismo antes de ser compreendida: proposta no início dos anos 1990, a virada pictórica/icônica propunha à historiografia conferir cidadania plena às formas visuais como acesso e visualização do passado. 0 problema central deste texto é saber qual o impacto especificamente historiográfico e de acesso ao passado trazido pela virada visual.

O reconhecimento da alteridade da imagem no paradigma/tropo da "virada visual" parece ser um novo horizonte de trabalho para os historiadores e apresenta algumas implicações na pragmática do produzir e veicular o conhecimento histórico. Nomeada e conceituada fora da historiografia, a virada à imagem teve um "duplo batismo", primeiro como pictorial turn por W. J. T. Mitchell, em 1992, nos EUA, estando na base dos visual studies e, depois na Alemanha, como iconic turn, por Gottfried Boehm, em 1994, na base da Bildwissenschaft (a ciência da imagem). Paralelamente, na França, a théorie de l'image tomava forma e consolidava uma reflexão densa interdisciplinar que designava a alteridade da imagem e seu papel na conformação e constituição do saber sobre o mundo, sendo a sintomatologia e a teoria do anacronismo de Georges Didi-Huberman seus mais famosos expoentes. Essas preocupações acadêmicas evidenciam o papel das imagens na sociedade contemporânea e a presença de certa ansiedade por elas causada no espaço público. Como argumenta Mitchell, a ansiedade pelas imagens gera sua repressão e/ou uma reação a essa repressão².

O ponto de vista desenvolvido neste texto parte da tradição historiográfica que atualmente vigora na formação disciplinar do historiador nas universidades pelo mundo afora. Essa tradição - no Brasil e fora dele - teve uma relação dúbia de aproximação e

\footnotetext{
${ }^{2}$ A repressão das imagens é uma chave interpretativa dos visual studies e da bildwissenschaft com grande potência para uma história da historiografia. Sintomático que as introduções, resenhas ou textbook sobre os temas história cultural, história e imagem ou história e iconografia iniciem a argumentação com a constatação sobre a falta (ou presença) de imagens na tradição historiográfica, sobre a necessidade de construir habilidades para lidar com imagens (CARDOSO; MAUAD, 1997), a subcidadania histórica destas na pesquisa histórica (MENESES, 2012) ou a enumeração dos precursores historiográficos da virada pictórica numa constelação de autores que contempla de Aby Warburg a Gilberto Freyre (BURKE, 2017; PESAVENTO, 2003). Uma pesquisa interessante seria indagar sobre os topoi da repressão visual no discurso historiográfico, ressaltados nas defesas das "vantagens" da virada visual.
} 
repressão das imagens. Outras tradições historiográficas, como a história da arte e da literatura, nunca tiveram uma posição repressiva com tais artefatos; mas tais "histórias axiológicas" foram muito historicamente criticadas (aquela que grosso modo se ocupa de temas e objetos da política, da sociedade, dos governos, da economia e, mais atualmente, da cultura). Retoma-se aqui a distinção entre valoração, história axiológica e história pura, realizada a partir de Max Weber, a qual corresponderia, grosso modo, um historiador puro e um historiador axiológico e teve grande fortuna nos estudos históricos em geral. Se a história (no singular) se interessa por aquilo "que foi", ou seja, os fatos causalmente importantes por sua conexão histórica, as histórias (no plural) que concebem seus objetos "por si mesmos" seriam do tipo axiológico, como as da literatura e da arte. Estas compreenderiam dois momentos: uma valoração/distinção preliminar (de obras e sujeitos) e uma história dos objetos selecionados. As chaves da virada visual e da cultura visual claramente embaralham essas tradições e colocam em perspectiva tais divisões disciplinares 3 .

No Brasil, a virada visual foi popularizada por Ulpiano Bezerra de Meneses (2004) e por Paulo Knauss Mendonça $(2006,2008)$ os quais apresentaram problemas, conceitos, propostas e vasta bibliografia internacional. Manoel Salgado Guimarães (2007) rapidamente captou as implicações daquela problemática e tentou articular a proposta em uma perspectiva de uma história da história escrita/visualização do passado:

É importante termos claro que, no caso do trabalho do historiador, essa relação entre o visível e o invisível parece revestir-se de uma peculiaridade, pois não se trata apenas de imaginar e visualizar o passado como algo irreal, fora da realidade presente à experiência sensorial [o invisível], mas como algo anterior ao nosso tempo, o que configura, portanto, uma especificidade a este ausente a ser visualizado: o de ser anterior ao nosso tempo e que, por isso, mantém com ele certas relações. Esta discussão implica necessariamente um cuidado, no sentido de precisar os termos com que operamos, que se torna evidente já na definição do que seria a visualização do passado, implicada tanto numa narrativa escrita sobre eventos pretéritos (que supõe do leitor uma imaginação do que está sendo narrado) como também num projeto de patrimonialização desse mesmo passado em instituições que dão suporte a esta visualização como, por exemplo, os museus. (GUIMARÃES, 2007, p. 11 , grifo nosso)

\footnotetext{
${ }^{3}$ Como veremos adiante, a rigor, a história da arte sempre embaralhou tais categorias e apenas do ponto de vista dos (que idealmente deveriam ser não-axiológicos). O problema do juízo e valor na história da arte mereceria uma reflexão que infelizmente não cabe aqui.
} 
Como aponta Guimarães, a visualidade no/do passado, a escrita da história e as formas patrimoniais (e públicas) de visibilidade (discursiva e material) do passado articulam uma experiência social de tempo e historicidade, o que significa um horizonte histórico-historiográfico além do paradigma imediato da prova. Talvez essa seja a virada à imagem historiográfica, que torna a imagem parte do processo de presentificar/diferenciar o passado em sua dimensão pública. O que talvez mais chame atenção sejam os problemas do: acesso ao passado por imagens; seu impacto na heurística e no estatuto da fonte histórica; os conceitos de temporalidade e historicidade; a visualização do passado na sociedade. Esses sãos os termos-chaves a serem tratados neste texto.

Este texto está dividido em três partes: primeiro apresenta três das principais representantes da virada imagética na atualidade, quais sejam, a pictorial turn de W. J. T. Mitchell, a iconic turn de Gottfried Boehm e a sintomatologia de Georges Didi-Huberman. A segunda articula as implicações históricas e historiográficas da virada visual. A terceira reorganiza o problema da fonte, da temporalidade e da visualidade/visibilidade pública do passado. Nas considerações finais, retomamos a dimensão pública da virada visual e do papel do historiador/professor.

\section{Da repressão à alteridade da imagem}

No cenário que propomos, imagem, cultura visual e virada pictórica/icônica/visual são termos correlacionados, cada qual, porém, tendo uma genealogia diversa. A reconstrução da reflexão sobre a imagem está fora da alçada deste artigo, sendo velha como a filosofia4. Já o uso do termo "cultura visual" remete aos anos 1920, embora

\footnotetext{
${ }^{4}$ Destacamos três referências basilares: PANOFSKY, Erwin. Idea: a evolução do conceito de belo. 2 ed. São Paulo: Martins Fontes, 2013; JAY, Martin. Downcast eyes: the Denigration of Vision in Twentieth-Century French Thought. Los Angeles: University of California Press, 1993; PINOTTI, Andrea; SOMAINI, Antonio (orgs.). Cultura visuale: imagine, sguardo, media, dispositivi. Milano: Einaudi, 2016. Sobre a formação do conceito de imagem no ocidente: GOMBRICH, Ernest. Arte e ilusão. São Paulo: Martins Fontes, 1995; VERNANT, Jean-Pierre. Da presentificação do invisível à imitação da aparência. In: Entre mito e política. 2 ed. São Paulo: EDUSP, 2002. p. 295-308; SCHMITT, Jean-Claude. O corpo das imagens: ensaios sobre a cultura visual na Idade Media. São Carlos, SP: EDUSC, 2007.; MONDZAIN, Marie-José. Imagem, ícone, economia: as fontes bizantinas do imaginário contemporâneo. São Paulo: Contraponto, 2013.
} 
apenas nos anos 1980 tenha começado a se afirmar ${ }^{5}$. As variações da virada à imagem (pictórica, icônica, visual, etc.) por sua vez, têm uma existência recente e foi uma reação ao absolutismo disciplinar da virada linguística proposta por Richard Rorty (SANTIAGO JR., 2019). Da preocupação com artefatos visuais e com os recursos teóricos usados para enfrentá-los, resultou uma discussão na qual termos como olhar, imagem e cultura visual tornaram-se chaves, e, no início dos anos 1990, simultaneamente nos EUA (por W. J. T. Mitchell) e Alemanha (por Gottfried Boehm), passou-se a usar a metáfora absoluta ${ }^{6}$ da virada pictorial/iconic como chave do deslocamento epistemológico produzido pela imagem e visualidade nos campos das humanidades. No caso do ambiente acadêmico francês, malgrado não tenha se falado espontaneamente de uma virada, a história da arte e a filosofia da arte francesa passaram pelo mesmo deslocamento com as propostas da théorie de l'image, destacando-se nesta, as obras de Didi-Huberman.

É preciso ter em mente a dimensão histórica que todas essas correntes apresentavam. A maioria dos estudiosos considera a emergência da sociedade de massas ou do espetáculo, como o momento no qual a sensibilidade para o papel das imagens se tornou decisiva na percepção das relações sociais (BRENNAN; JAY, 1995; COSTA; SCHIAVINATTO, 2016; MENDONÇA, 2006; MENESES, 2004; MIRZOEFF, 1999, 2018; MOXEY, 2008; PINOTTI; SOMAINI, 2009, 2016). Contudo, é preciso evitar o discurso novidadeiro e evidenciar que foram, por exemplo, as pesquisas de história da arte sobre o medievo e o renascimento que, junto àquelas sobre a história da modernidade industrial, propuseram modelos históricos e antropológicos pertinentes para uma abordagem diferenciada das imagens.

\footnotetext{
${ }^{5}$ Embora alguns defendam Towards a visual culture, de 1969, de Caleb Gattegno (DIKOVITSKAYA, 2006) como o primeiro texto de destaque a usar o termo cultura visual, expressão mais tarde capitalizada pelos trabalhos de John Berger e Michael Baxandall (1991), quem primeiro o tornou famoso foi o livro de Svetlana Alpers, A Arte de Descrever, de 1983. Contudo, a expressão fora elaborada na teoria do cinema de Béla Balázs (em 1924 no volume L’uomo visibile) e por László Moholy-Nagy. Cf.: Pinotti; Somaini, 2016; Balázs, 2008, Costa; Schiavinatto, 2016.

${ }^{6}$ Usando a metaforologia de Hans Blumenberg, nos distanciamos da tropologia de Hayden White ou Frank Ankersmith, para quem metáforas são recursos retóricos, enquanto para Blumenberg, em sentido etimológico, são enfrentamentos do mundo, formas de se orientar no confronto com a realidade (BODEI, 1989, p. xx). O termo virada é uma metáfora absoluta, um símbolo articulador de conceitos, como na concepção de Hans Blumenberg (2018), ou seja, um modelo em função pragmática do qual se obtém uma maneira de refletir. É uma “forma da reflexão", e não o seu conteúdo.
} 
Quando as viradas à imagem foram propostas no início dos anos 1990, as suas bases já eram resultados de pesquisas em muitas disciplinas (história da arte, história do cinema, história das tecnologias, antropologia visual, psicanálise, psicologia cognitiva, etc.) sobre alguns aspectos centrais: 1) as mídias (orais, impressas, visuais) como tecnologias sociais da comunicação com implicações cognitivas, sendo, portanto, tecnologias do pensamento (GOODY, 2012; SAMAIN, 2001); 2) o olhar como uma organização do campo cognitivo historicamente construído (BAXANDALL, 1991; ALPERS, 1999) que implica na produção das diferenças e identidades sociais; 4) as imagens como dotadas de diferentes estatutos sociais e epistêmicos nos tempos e nos espaços (BELTING, 2013; DEBRAY, 1993; VERNANT, 2002); 5) o ver como algo que se faz, um tipo de performance através de técnicas em corpos e materiais (MIRZOEFF, 2018) e as imagens como sujeitas socialmente a usos diversos (ALPERS, 1999; BAXANDALL, 1991; CRARY, 2012; GUNNING, 1991); 6) as imagens como fundamento da produção do conhecimento socialmente compartilhado, inclusive do científico (BREDEKAMP, 2015; GUNNING, 1991; KEMP, 1990; MEAD; BATESON, 1942; YATES, 2007; MAUAD, LOPES, 2014). Tais aspectos, recolhidos como resultados de pesquisas, foram convertidos em premissas dos estudos da história das imagens socialmente atuantes.

A consequência dos resultados acima foi passar a considerar que a imagem estava cada vez mais além/aquém dos paradigmas textuais/linguísticos de explicação, demandando uma abordagem própria. O mundo cognoscível seria historicamente montado pela relação da imagem com sua alteridade - a linguagem - e se era possível demostrar a historicidade das formas e atividades visuais, era possível localizar fenômenos que só ocorriam pela especificidade visual, o que implicava em uma epistemologia própria. Os visual studies, a Bildwissenschaft e a théorie de l'image definiram esse quadro epistêmico.

Paulo Knauss Mendonça (2008) já apresentou o campo dos visual studies e da Bildwissenschaft. Pode-se dizer que os estudos visuais ou visual culture studies são um rebento interdisciplinar anglo-americano das pesquisas sobre olhar, tecnologias visuais e imagens desenvolvidas na história social da arte, história do cinema, estudos feministas, antropologia, história das tecnologias e estudos culturais. Seu ponto de inflexão parece 
ter sido a teoria do olhar feminista, as pesquisas sobre experiência visual de Michael Baxandall (1991) e Svetlana Alpers (1999), a reflexão sobre iconologia e regimes escópicos de W. J. T. Mitchell e Martin Jay e as pesquisas sobre dispositivos visuais de Jonathan Crary e Thomas Gunnning. A Bildwissenschaft (ciência da imagem) se desenvolveu na Alemanha tendo como seus antecedentes o puro visualismo austríaco e a ciência da cultura de Aby Warburg (2005), os quais foram retomados no final dos anos 1960 e início dos anos 1970 no diálogo da história da arte com a filosofia, especialmente com a hermenêutica de Hans-Georg Gadamer. Procurava-se uma heurística diferenciada que apontasse para uma dêitica7 das imagens (MONTE; MONTE, 2009, p. 24). Interessada na passagem do medievo ao renascimento e dialogando com a arte moderna, formava-se uma história da arte que partia do espectro do termo imagem (bild ${ }^{8}$ ) em alemão a partir do horizonte da história da arte. As concepções de iconicidade de Max Imdhal e Gottfried Boehm, da diferença entre imagens e arte, de Hans Belting (2013), e do papel das tecnologias na elaboração do conhecimento, por Horst Bredekamp (2015), foram alguns dos focos de trabalho.

Na França, como desdobramento da reflexão fenomenológica, da psicanálise lacaniana e a função escópica do olhar, da teoria do cinema francês e da arque-genealogia de Michel Foucault, a imagem e o olhar se colocaram como uma questão fulcral. JeanPierre Vernant (2002) já havia demonstrado o estatuto histórico da imagem, ao mesmo tempo em que o estatuto da representação era revisado pela filosofia da diferença ${ }^{9}$ e seus colaboradores $^{10}$. A théorie de l'image desenvolvia-se nos anos 1980 conduzindo a uma

\footnotetext{
7 Uma dêitica permite realçar o que de não-linguagem há numa imagem/artefato que se oferece à visão de qualquer pessoa. Valoriza a presença do material no qual emerge a imagem, dotado de uma contiguidade espacial em sua manifestação (Moxey, 2008). Gumbrecht (2010) define a presença como não-linguagem em abordagem não-hermenêutica: a proposta é usar as palavras "que apontam para as coisas", não as que as substituem.

8 Bredekamp (2003) afirma, em defesa da "tradição negligenciada", qual seja "a ciência da imagem" (Bildwissenschaft), que a divisão artificial entre arte e imagem trabalha a partir da palavra alemã "bild", a qual compreende a imagem (image), a imagem material (picture), a figura (figure) e a ilustração (illustration). Publicado em Critical Inquiry, uma das revistas-chaves do debate sobre cultura visual nos EUA, foi uma provocação ao meio intelectual dos infantes visual studies. Cf. MENDONÇA, 2008.

9 Entendendo os trabalhos filosóficos de Michel Foucault, Gilles Deleuze, Jacques Derrida, Clement Rosset como compositores de uma filosofia da diferença de matriz nietzschiana. Entre os colaboradores desta ampla reflexão, encontraram-se Louis Marin e Régis Debray.

10 Notadamente as obras de Guy Debord e Jean Baudriallard. Martin Jay (1993) designou a relação problemática da filosofia francesa com as imagens, marcada por uma sensível desconfiança num movimento de repressão, e, ao mesmo tempo, por uma constante atração por elas.
} 
pungente reflexão a partir da história da arte. Nascida do debate entre filosofia, psicanálise e história da arte, as obras de Humbert Damisch, Daniel Arasse, Philippe Dubois, Jacques Wunenburger e Georges Didi-Huberman - incluindo ainda reflexões de Jacques Rancière e Jean-Luc Nancy - conduziram a novos paradigmas sobre a imagem no meio francófono. Os anos 1990 viram a revisão dos pressupostos epistemológicos da relação entre historiografia e imagem, destacando-se a obra original de Georges DidiHuberman, marcadamente iconoclasta com os pais oficiais da história da arte (notadamente Erwin Panofsky) e da história social da arte (especialmente Michael Baxandall e Svetlana Alpers) ${ }^{11}$.

Após a onda estruturalista e a afirmação da virada linguística, foi na passagem dos anos 1970 aos 1980 que se começou a deslocar a imagem do paradigma da linguagem. No contexto alemão, Gottfried Boehm (1981) ${ }^{12}$ dedicou-se a encontrar as evidências de um pensamento filosófico no qual a imagem emergisse como um tópico que desafiasse a preponderância do discursivo. Em uma investigação do que chamava de hermenêutica da imagem elaborou a noção de diferença icônica (BOEHM, 2012). Boehm postulou a diferença $a^{13}$ "entre a superfície e o elemento que se encontra nela se produz uma relação. O olho percebe uma ligação, não um signo, e nem mesmo uma figura. A ligação permite perceber aquilo que se vê enquanto tal” (BOEHM, 1981, p. 124). A separação ou diferença “dos elementos que se encontram sobre a superfície da superfície em si mesma produz uma tensão", a diferença icônica (BOEHM, 1981, p. 125), seria uma condição cognitiva e antropológica.

Em 1984, W. J. T. Mitchell (1986) sistematizou muitas das suas ideias almejando demonstrar que os modos de compreensão teórica das imagens "se baseiam em práticas sociais e culturais em uma história que é fundamental para a nossa compreensão não só

\footnotetext{
${ }^{11}$ Didi-Huberman (2016) criticava a ideia de cultura e experiência visuais como recursos heurísticos capazes de reconstruir a experiência histórica visual e imagética do passado como pretendiam os seus propositores originais, notadamente Baxandall e Alpers.

12 Até a escrita deste texto, o único texto de autoria de Boehm traduzido para o português encontra-se na coletânea Pensar a Imagem (Alloa, 2013).

13 Claramente baseada na diferença ontológica de Martin Heidegger, que enfrentava a metafísica por uma diferenciação voltada a romper a normalidade/cotidianidade na qual o ser mergulharia o mundo. Boehm considerava que a epistemologia linguística normalizava os fenômenos imagéticos, devendo-se fazer o caminho inverso. Cf.: BOEHM, 2009, 2013.
} 
das imagens, mas também do que a natureza humana poderia ser" (MITCHELL, 1986, p. 504, grifo nosso). Postulava que a relação entre imagem e discursos não era uma questão de natureza, mas das práticas sociais e culturais ligadas ao uso desses termos e a definição de seu universo de circulação. Mitchell afirmava que a imagem é uma alteridade da linguagem e que apenas a história das ansiedades e conceitos a ela associados podia definir o seu funcionamento. Uma vez que entre linguagem e imagem haveria perturbações mútuas, o esforço da filosofia e dos usos cotidianos da imagem foi de reprimi-la por causa das tensões estéticas e sociais por ela ativadas, entre outros por sua alteridade em relação à linguagem. Mitchell propunha a "consciência da irredutível coexistência e convergência do visivo e do verbal em ambos os sistemas comunicativos e semióticos" (COMETA, 2017, p. 18-19).

Didi-Huberman propunha inicialmente um paradigma da imagem como “encarnação" ${ }^{14 " ~ d e ~ s i n t o m a s ~ i n v e s t i d o s ~ p e l o s ~ s u j e i t o s ~(D I D I-H U B E R M A N, ~ 2013) ~}$ desenvolvendo um projeto histórico-filosófico com o pressuposto da imagem como corpo e sujeito do investimento afetivo e significativo por ela aberto. O historiador desenvolveu a perspectiva de que cada imagem demanda um discurso específico ao qual o historiador deve localizar para abri-lhe ao pensamento e à reconstrução do passado. Como historiador-filósofo, Didi-Huberman articulou uma revisão da história da historiografia da arte a partir da hipótese da singularidade das imagens, identificando formas de evidenciar as singularidades reprimidas pelos discursos fundadores da história da arte institucionalizada.

Os três autores, entre outros, promoviam uma acepção diferenciada da imagem em relação ao espectador e ao discurso e foi a partir dessas diferentes matrizes que se lançaram, cada qual, sua virada à imagem. Pioneiro, W. J. T. Mitchell no artigo The Pictorial Turn defendeu que o confronto entre as diferenças visuais e textuais são sempre diferenças de cunho social15. Mitchell retomava a diferença fundamental entre image e

\footnotetext{
14 Para Didi-Huberman, a encarnação permite que os olhos contemplem a superfície e a perpasse para chegar à profundidade da afecção e significado da obra. O autor trata dos duplos sentidos do termo, os quais, tecnicamente, envolvem a carnação, a camada de tinta que simula a carne e pele e reveste a anatomia corporal humana na pintura, e o princípio teológico da encarnação de Deus, invisível no corpo visível de Jesus.

15 O texto foi republicado dois anos depois como primeiro capítulo de Picture Theory, coletânea de textos de Mitchell de 1994. Foi naquele momento que a pictorial turn ficou famosa.
} 
picture, inexistente em português: em língua inglesa, image é a palavra usada para designar a coisa intangível que se materializa em pictures, termo que definia o espectro das experiências com artefatos, práticas, usos e materialização de imagens. Afastando-se de um conceito abstrato de imagem, Mitchell focava na ligação histórico-social determinada entre produções de imagens, novas tecnologias e "as profundas mudanças antropológicas que comportam" (COMETA; 2017, p. 26), por meio das quais se podia localizar a "especificidade não textual das imagens" (COMETA, 2017, p. 21). A “virada pictórica" evidenciava que as imagens haviam sido secundarizadas como textos pela virada linguística de Rorty. A espectorialidade (a visão, o olhar, a mirada, as práticas de observação, vigilância e prazer visual) e a experiência visual não podiam ser explicadas pelo modelo linguístico, o qual só poderia ser combatido por meio de uma concepção de imagem como paradigma \& anomalia ${ }^{16}$, uma alteridade da linguagem e considerá-la (a imagem) como histórica articuladora das alteridades sociais. Destaque-se que para Mitchell, os visual studies são apenas face acadêmica da pictorial turn (MITCHELL, 1994, 2015) e que a repressão das imagens é um problema amplo da esfera pública. A virada é um fenômeno histórico recorrente de reação às formas visuais, sendo as suas variações tecnológicas como a fotografia/cinema/televisão/internet apenas a sua atual face pública novidadeira.

O outro momento de batismo da virada foi o ensaio O Retorno das imagens, no qual Gottfried Boem (2009a) lançou o termo iconic turn/ikonischen wendung, sistematizando o programa de investigação da diferença icônica. O texto era a introdução da coletânea alemã Wast ist ein Bild? (“O que é uma imagem?”), o qual fora concebido para apresentar, de uma forma sistemática, para o público alemão, a fortuna crítica a qual Boehm considerava precursora da virada icônica. Boehm, ironicamente, sugeria que a linguistic turn convertera a linguagem em um deus in machina. O "retorno" das imagens seria a própria virada para tematizar a diferença icônica, ou seja, o "lugar nativo de todo sentido de imaginal" e "a potência ao mesmo tempo visiva e lógica das imagens" (BOEHM, 2009a, p. 58), na constituição da relação do homem com artefatos e o mundo. Os corpos visivos das imagens são formas presenciais e sensoriais e demandam

\footnotetext{
${ }^{16}$ Mitchell considera a dupla image/picture, a qual combina paradigma (campo de compreensão do trabalho investigativo) e anomalia (desvio que o paradigma não contempla). Cf. MAUAD, 2016.
} 
especificação para investigação das práticas imaginais/visuais humanas em suas condições ontológicas-antropológicas e histórico-culturais. A imagem é a produção do afeto e conhecimento e as formas sociais de sua produção delimitam o acesso, as hierarquias e a organização da realidade.

Por fim, Georges Didi-Huberman, a partir de Ce que nous voyons, ce qui nous regarde (DIDI-HUBERMAN, 1998), consolidou uma visão nietzschiana/anti-historicista da temporalidade. O centro irradiador dessa reflexão foi a imagem-dialética, o instante do retorno do passado como imagem/memória que lança o tempo na anacronia de um presente repleto de passados sobreviventes. Didi-Huberman (2013) passaria a defender um interesse pela memória das imagens que seria articulável em uma escrita e pensamento histórico de montagem. Este partia do impreciso próprio da imagem e se deslocava entre imagens-fragmentos no/do tempo. Propunha a associação entre peças (imagens) de uma conjectura que deve ser ricamente documentada em uma reconstrução de contextos históricos em permanente diálogo com o presente do historiador. 0 discurso histórico, como conjectura sobre o passado, é uma tensão com a presença visual (a imagem) com a qual se contacta. A imagem é uma forma "energética", sintoma das forças que, compostas de múltiplas temporalidades e possuindo ritmos diferenciados, se tensionam nela para afirmar a própria existência. Ela é sintoma dos ritmos temporais dessas forças e por isso não é fonte ou documento, intervindo diretamente na formulação da questão histórica; ou seja, a dúvida metódica que faz da imagem capaz de acessar os passados trata o encontro do historiador com a fonte como uma maneira de sintomatizar o encontro das demandas já portadas pela imagem como memória/passado e os interesses dos agentes do presente. Didi-Huberman (2013) compreende a cultura de um outro período temporal como um elemento no jogo histórico, e a vida da imagem como a inevitabilidade relacional, na qual, simultaneamente ela tem funções (uma antropologia), formas (uma morfologia) e forças (uma energia). Esse último aspecto sintomático, ou seja, como emaranhado de forças em conflagração que perturba os jogos discursivos (DIDI-HUBERMAN, 1998) é a base da "concepção indefinida" da imagem como alteridade da parte de Didi-Huberman. A rigor, A rigor, o autor propõe uma sintomatologia que é outra forma de iconologia (ALLOA, 2012). 


\section{No rumo da historiografia das imagens - outros problemas históricos}

Os aspectos apontados acima têm sido, nos últimos anos, traduzidos para o debate historiográfico. Hoje ninguém seria capaz de negar a importância das imagens para realização da pesquisa e escrita historiográfica. Porém, já deve ter ficado claro que a cultura visual e a virada visual não foram concepções que se desdobraram inicialmente no trabalho da "historiografia pura" ou "geral", aquela voltada aos temas convencionais da política e economia, sociedade e cultura. Foram concebidas nos lugares institucionais das que já foram chamadas de "histórias axiológicas", outras tradições historicamente mais sensíveis às imagens (história da arte, história do cinema, fotografia e dos dispositivos visuais) ${ }^{17}$. A ciência da história era/é uma escrita e fora montada como disciplina a partir da mediação dos documentos escritos, de maneira que o paradigma textual era (é) muito forte e voltado a um princípio do acontecimento singular de dimensão "histórica", sendo que "histórico" era tudo aquilo que dizia respeito, em sua emergência, ao poder/governo, trabalho/economia/mercado e, mais tarde, grupos sociais e práticas culturais. Contudo, já havia um diálogo de destaque da historiografia com as concepções de imagens diferenciadas, destacando-se aqui a história da arte e da fotografia. Ou seja, se como concepções, virada visual e cultura visual não parecem ter sido nativas, como forma de problematização, a coisa pode ter sido diferente.

No Brasil, foi no desdobramento das pesquisas com material visual que novas formas de problematizar a imagem, tanto pela história da arte, como pela historiografia tradicional, se desenvolveram. A importância dos acervos de arte e museus se destaca na formação de estudiosos na passagem dos anos 1980 aos anos 1990 (MENDONÇA, 2016) e, ainda que a história da arte não tenha conseguido se institucionalizar no Brasil (CONDURU, 2016), muito por resistência da historiografia tradicional (VIVAS, 2011), uma

\footnotetext{
${ }^{17}$ As "histórias axiológicas" compreenderiam dois momentos: uma valoração/distinção preliminar (de obras e sujeitos) e uma história dos objetos selecionados. Paul Veyne (1973), anos depois de Max Weber, retomou essa distinção para afirmar que "história" não se ocuparia das obras-primas e artistas. Segundo Veyne, uma história axiológica (da arte, literatura, ciência) pode se transformar em "história" se se faz como história da arte, literatura ou ciência de seu tempo. Curiosamente, muitas historiografias da literatura e das artes estão na base de inovações historiográficas da segunda metade do século XX (Erich Auerbach, Ernest Curtius, Norphorf Fry, Aby Warburg, Edward Wind, Fritz Saxl, Roberto Longhi) e o desenvolvimento das histórias da historiografia da arte e da literatura tem revelado mais aspectos de "história" em historiadores axiológicos do que se estava disposto a aceitar.
} 
reformulação de currículos e perspectivas se formou desde os anos 1990 (COLI, 2007; KERN, 1996 2005) e se consolidaria em novas propostas nos anos 2000 (COLI, 2007; CONDURU, 2016, KAUFMANN, 2016). Maria Lúcia Kern (1996) explicitava, por exemplo, como a Nova História de matriz francesa havia sido importante para rearticular, no Brasil, as propostas específicas da história da $a r t{ }^{18}$. Uma marca dessa renovação foi "a desnaturalização do olhar como problema de fundo" (MENDONÇA, 2016, p. 16) das pesquisas com artefatos e imagens.

Destaque-se os estudos pioneiros com material fotográfico, em especial os estudos de história da fotografia (KOSSOY, 1994) e aqueles sobre usos de funções da fotografia e seus circuitos sociais, entre os quais se ressalta a importância às abordagens da cultura material (CARVALHO; LIMA, 1993) e sobre códigos de representação, na perspectiva pioneira de Ana Maria Mauad (1990). Esta última trabalhava a partir da historiografia tradicional, entendendo uma relação direta com a renovação proposta pela Nova História. Tais pesquisas visavam responder dúvidas sobre conjunturas históricas nas quais as imagens ocuparam papéis de destaque: qual o papel das aquarelas, pinturas e gravuras de Carlos Julião, Debret e Rugendas na história do trabalho e da cultura de africanos escravizados dos séculos XVIII e XIX? (SLENES, 1995; LARA, 2007; LIMA, 2007). De que maneira a fotografia participou da formação da identidade das elites paulistanas e cariocas ou das populações negras do período imperial e do início do período republicano (MAUAD, 1997; FABRIS, 1998) ou da composição de um olhar sobre alteridade no século XIX? (MAUAD, 1997, 2008). Como a fotografia permite compreender práticas culturais e participa da configuração da cultura urbana moderna no Brasil republicano? (CARVALHO; LIMA, 1997; FABRIS, 1998). Qual o papel da liturgia política nas festas e das cerimônias na autonomização do Brasil no século XIX? (SCHIAVINATTO, 1999). Como a escultura e arte públicas organizam e criam usos e pertencimentos urbanos no Rio de Janeiro? (MENDONÇA, 1998). De que maneira a idealização de estilos arquitetônicos, pelas elites culturais, construiu o pertencimento patrimonial no século XIX? (MENEGUELLO, 2008). Como a cultura do objeto configura e organiza os espaços domésticos das elites?

\footnotetext{
${ }^{18}$ Não sem tensões: Rodrigo Vivas (2011) afirma que a busca de diálogo com a Nova História criou certa incompreensão do verdadeiro papel da história da arte na consolidação de estudos da arte. A argumentação de Rafael Cardoso (2009) vai na mesma direção.
} 
(CARVALHO, 2004). Como a pintura acadêmica oitocentista participou da criação do Império do Brasil? (COLI, 1998; SCHWARCZ, 1998, 2008). Como a busca pela identidade nacional transformou o cinema num ato político (SCHVARZMAN, 2004) e como foram usadas imagens e discursos históricos na autenticação de discursos fílmicos (MORETTIN, 2013)? A partir dessas perguntas, na organização dos dados, na delimitação dos métodos, na sistematização de conceitos, foram tematizadas a imagem, a visualidade e a cultura visual. Quando Ulpiano Meneses (2004) publicou Fontes visuais, cultura visual, história visual, muitos historiadores (MAUAD, 2016, MENDONÇA, 2016; SCHIAVINATTO; ZERWES, 2019) se reconheceram no empreendimento teorizado no debate estrangeiro sobre virada visual e cultura visual. O texto apresentava muitos conceitos que já eram aplicados na prática historiográfica e apresentou novas ideias que deram impulso ao debate sobre a visualidade.

Obviamente, as imagens não eram novidades na história, muito menos na história da $a^{19} \mathrm{e}^{19}$. Apesar de recorrerem às obras de arte e às imagens - em alguns casos com mais destaque, como Johan Huizinga ${ }^{20}$, e, outros com menos, como Fernand Braudel ${ }^{21}$ apenas depois dos anos 1960 em diante, com a terceira geração dos Annales, a “historiografia tradicional" instaurou um interesse oficial (MAUAD, 2016; KERN, 1996; BURKE, 2017) por imagens como fontes históricas. As fontes visuais foram oficializadas na ciência da história por meio de uma história social que se interessava por temas como magia, religião, religiosidade, família, infância e morte (MAUAD, 1990; BURKE; 2017). Se a Nouvelle histoire e sua abertura aos temas, problemas e objetos abriu caminho de forma irreversível para novas fontes (ex-votos, construções, filmes, quadros, túmulos, gravuras,

\footnotetext{
19 Motivada pela atuação do Warburg Institut na Inglaterra, por exemplo. Hugh Trevor-Roper (LLOYDJONES; BLAIR, 1981) e Christopher Hill (1992), entre outros, dialogavam com os trabalhos sobre religiosidade renascentista, mnemotécnica e esoterismo do Warburg Institut, como Donald Clark (2007) e Frances Yates (2007). A noção de imagem como forma cognitiva, ou dos artefatos visuais, apareciam nos trabalhos de Clark, Yates e também dos filósofos-historiadores das ideias italianos, Paolo Rossi (2004) e Eugenio Garin (1987). As obras de Yates, Clark, Rossi e Garin foram fundamentais para historiadores como Le Goff ou Ginzburg.

${ }^{20}$ Cite-se Outono da Idade Média, obra que explora de inúmeras metáforas visuais. A obra de Huizinga se destaca pelo uso de imagens, ele próprio "herdeiro" da tradição de Jacob Burkhadtt, contra o qual se contrapunha. Como se sabe, Burkhardt encontra-se na base de todo um conjunto de concepções estéticas (Nietzsche) e historiográficas (Huizinga, Wolffling, Riegl, Warburg) do século XIX-XX. Cf. FERNANDES, 2006.

${ }^{21} \mathrm{O}$ texto $\mathrm{O}$ Modelo Italiano, de Braudel (2007b), é sui generis na bibliografia braudeliana.
} 
esculturas, etc.) dos anos 1970 em diante, as imagens conseguiram seu lugar na “historiografia": incialmente relacionadas com as "mentalidades", foram deslocadas para a "história social da cultura", e depois para uma "história cultural do social" (CHARTIER, 1991, p. 180), a qual ficou conhecida como nova história cultural (HUNT, 2001). A iconografia "entrara” para a história.

Contudo, considerar a imagem como "testemunha ocular" (BURKE, 2017), ou seja, usá-la como "evidência histórica" não é o mesmo que tratá-la como funcionalizadora das relações sociais e formuladora de uma historicidade diferenciada, como apontam os estudiosos - a "tríade" Mitchell, Boehm e Didi-Huberman - tratados no tópico anteriormente. Na história cultural ou história social da cultura, muitas obras já apresentavam interlocução direta com as pesquisas que seriam constitutivas da nascente história da cultura visual, destacando-se o diálogo com as diversas tradições da história (social) da arte e/ou as novas histórias dos dispositivos visuais.

Tais trabalhos eram interessados em romper a dicotomia imagem $x$ sociedade ou 0 mero uso da imagem como fonte histórica e apontavam à necessidade de romper os modelos textuais em uma indagação diferenciada para as imagens:

Quando o historiador não consegue moderar a força gravitacional da palavra, tende a transformar a imagem em texto, e o pior nisso é que se esvazia ou deforma a natureza visual da imagem visual, que passa a ser tratada como um recipiente neutro (...) se faz dos objetos mera duplicação de um discurso verbal ou verbalizável, desprezando a materialidade não verbal do meio empregado e, por outro lado, ignorando que tanto a ideia produz a forma, quanto é produzida por ela. (MENESES; 2012, p. 251).

Os primeiros compêndios a surgirem sobre cultura visual (JENKS, 1995; BRENNAN; JAY, 1995), após Picture Theory e de Wast ist ein Bild?, eram marcados por questionamentos, dúvidas e muitas disputas ${ }^{22}$. A partir dos anos 2000, a popularização das pesquisas da ciência das imagens alemã, por meio da publicação de textos de Horst Bredekamp (2003) e Hans Belting (2013), bem como a intensiva divulgação das obras de

\footnotetext{
${ }^{22}$ O dossiê da revista October, n. 77, de 1996, apresentando entrevistas com vários estudiosos, contava com uma avaliação negativa da proposta.
} 
Didi-Huberman ${ }^{23}$, abria espaço para um diálogo internacional. Foi naquele contexto que surgiu também o debate, no Brasil, com Ulpiano Meneses (2004) e Paulo Knauss Mendonça (2006).

Ao mesmo tempo em que Paulo Knauss Mendonça (2008) sistematizava para o público brasileiro os Visual studies e a Bildwissenschaft, evidenciando as perspectivas históricas de ambas, Keith Moxey (2008), nos EUA, popularizava um deslocamento epistemológico propriamente historiográfico, realizando a primeira comparação de destaque dos estudos anglo-americanos, franceses e alemães naquele país. Segundo o autor, haveria um modo anglo-americano hermenêutico de pensar as imagens como produtos culturais, que demandavam decodificação de significados, e os modos britânico, francês e, principalmente, alemão, segundo os quais as imagens como presenças-agentes provocavam respostas nos vedores (viewers). Moxey usava a expressão alemã iconic turn porque almejava destacar a abordagem de Boehm e aproximá-la da théorie de l'image que tinha em Didi-Huberman seu maior expoente (MAUAD, 2016).

No caso do Brasil, acrescente-se a intervenção de Manoel Salgado Guimarães (2007), que pensando a partir dos museus e do patrimônio histórico, concebia que parte do desafio ao conhecimento histórico contemporâneo era entender a forma como o passado era visualizado pelas instituições. Guimarães, Meneses, Mendonça e Moxey chamavam atenção às particulares relações do conhecimento historiográfico com as fontes visuais, a constituição do tempo e da memória e a elaboração da historicidade (das imagens e da operação historiográfica), em suma, do acesso ao passado por/como imagens.

Tudo parece apontar que a base histórica dos paradigmas da virada visual encontrou a autorreflexão propriamente historiográfica da tematização das imagens nos anos 2000, notadamente no Brasil. A “imagem testemunha ocular”, portanto, possui um plus quando pensada a partir do problema da cultura visual. A historiografia lida com a

\footnotetext{
${ }^{23}$ Havia poucas traduções de Didi-Huberman para o inglês, espanhol ou português até os anos 2000, sendo mais abundantes as traduções para alemão e italiano. A partir de 2005, houve um processo acelerado de traduções de suas obras para italiano, alemão, inglês e espanhol. O único texto traduzido em português até 2001 era Ce que nous voyons, ce qui nous regarde (O que vemos, o que nos olha). A partir de 2011, a obra do francês passou a ser sistematicamente traduzida para o português.
} 
perspectiva de que dois conceitos, quais sejam, imagem e cultura visual, são fenômenos/processos históricos presentes em diversas temporalidades. A diferenciação conceitual, neste caso - o que é uma imagem? - tornou-se fundamental para sistematizar o problema de a "imagem ser construída historicamente" e não ser "um objeto naturalmente dado" (SCHIAVINATTO; ZERWES, 2019, p. 15). Ora, isso implica saber como pensar historicamente a imagem.

Se a virada pictórica não parece ameaçar o estatuto do conhecimento histórico ${ }^{24}$, ela não deixa de ser uma tomada de posição incidente sobre a constituição desse conhecimento. Um primeiro problema a ser resolvido seria coordenar duas premissas bases: os diversos estatutos socioculturais das imagens nas diversas épocas; e uma escrita da história que articula essas diferenças ao redor de uma heurística da imagem:

Uma vez que as imagens foram diferentemente concebidas e percebidas em diversas épocas ou culturas históricas - motivo pelo qual daríamos conta de tais diferenças em chave teórica - faz-se inevitavelmente uma autocontradição no nível epistêmico. O problema lógico, de novo, é a comensurabilidade da diferença postulada (ou imaginada). Qual seja o grau de diversidade nas concepções das imagens presumidamente vigentes em um certo contexto distinto do nosso, não será de qualquer modo tanto radical para desfazer a identidade conceitual, de definição ou intuitiva do objeto ao qual se supõe seja uma concepção, a imagem mesma, a despeito da não individualidade da concepção em si mesma. Então não haveria tantas alternativas: se (1) as diferenças em questão são entendidas no sentido fraco (como uma pluralidade de pontos de vista a, b... $\mathrm{n}$ todos mensuráveis ao mesmo objeto $\mathrm{X}$ ), então é obvio que a perspectiva histórico-cultural ou histórico-conceitual não modifica $\mathrm{O}$ objeto e não impede uma idêntica cognição. Se, ao contrário, (2) as diferenças são assumidas em sentido forte, e comportariam pontos de vista historicamente incompatíveis ou incomensuráveis, estes podem ser realmente tais somente se, novamente, são comparáveis ao mesmo objeto $\mathrm{X}$, de outro modo (se revíssemos por hipóteses ou por acidente objetos diversos) não teria sentido dizer que são incompatíveis ou alternativos. (MONTE, 2012, p. 209-210)

Segundo Michele di Monte, o específico da imagem, cuja manifestação práticofenomênica é diversificada e variante em múltiplos contextos, encontra o problema falar/escrever sobre a historicidade do icônico. A virada visual sustenta uma apreciação histórica que pretende alcançar o passado pelas imagens as quais, malgrado sua

\footnotetext{
24 Isso ocorreu, por exemplo, com a tomada de consciência do papel da narrativa no conhecimento
} histórico nos anos 1970. 
especificidade e funcionamento contextual-histórico circunstancial, são, ainda, imagens ${ }^{25}$. Esse desafio permeia a historiografia desde as considerações de Jean-Pierre Vernant (2002), continuando na pesquisa sobre o estatuto da imagem entre ameríndios (GRUZINSKI, 2006), no cristianismo (BESANÇON, 1997; SCHMITT, 2007), no islamismo (BETTETINI, 2013), etc. Em especial, Ginzburg (2001) condensou todo esse problema em um texto que indaga sobre o estatuto histórico da prática da representação - e sua validade como conceito analítico histórico - sem apresentar uma conclusão definida. Se, antes, o problema, como achava Ginzburg (2001), era o estatuto histórico da representação, agora a pergunta se modificou: qual seria o estatuto histórico da diferença imagética?

As soluções a este problema têm sido variadas. Propomos algumas abordagenschaves desenvolvidas.

(1) A iconicidade como chave antropológica-ontológica com implicações historiográficas. Independentemente de ser considerada pela diferença icônica (via Boehm) ou pelo discurso singular requerido por cada imagem (via Didi-Huberman), esta como forma plástica/cognitiva, implica em um novo aprendizado do ofício do historiador. O que de fato se vê quando se mira uma imagem (construções de cores, formas, linhas que não podem ser descritas como signos), remete à necessidade da especialização de vocabulário descritivo da "lógica das imagens" (BOEHM, 2009b) a qual deve ser incorporada ao problema de pesquisa que está sendo desenvolvido. Por um lado, a iconicidade é uma questão de cultura material e das dimensões antropológicas da presença das imagens; por outro, resulta de práticas históricas de uso de material e constituição cognitiva. A antropologia histórica das imagens de Hans Belting (2013) e a análise histórica dos atos icônicos de Horst Bredekamp (2015) oferecem dois dos melhores modelos historiográficos nessa linha. Os trabalhos historiográficos de Serge Gruzinski (2006), Carlo Ginzburg e Jean-Claude Schmitt (2007) também trataram dessa

\footnotetext{
25 Nessa oscilação também se encontra todo o cerne dos atos icônicos de Bredekmap, a troca entre corpo, mídia, suporte de Belting (2005), e, claro as tensões dialéticas) de Georges Didi-Hubermam. Como sugeriu Emmanuelle Alloa, dentro da virada icônica apresenta-se uma renovada atenção pela "morphê, a aparição da forma, a morfologia e a sua metamorfose". Alloa sugere que a virada icônica é uma nova episteme na medida em que estende a questão do "eidos para além de uma eidética re-cognitiva" (ALLOA, 2012, p. 149).
} 
dimensão (diferença visual e prática cultural) sem se perder em labirintos conceituais de difícil trato. No geral, trata-se de identificar os aspectos importantes que a "natureza visual do documento" (MENESES, 2012, p. 253) acrescenta à vivência social justamente porque há singularidade da subjetividade individual e coletiva que usam tais elementos.

(2) A imagem como prática social é, talvez, a consequência/pressuposto mais importante da transformação das pesquisas históricas sobre a cultura visual e que demonstram o deslocamento produzido pela virada imagética. Tal perspectiva implicou na superação da teoria do reflexo e na aceitação da imagem como constitutiva das práticas sociais, inclusive em suas amplas atuações na cultura pública (MIRZOEFF, 2018; MITCHELL, 1994). A própria cultura visual pode ser pensada como um campo interdisciplinar de estudo das práticas do olhar (MENDONÇA, 2016). A imagem envolve uma indexação (GELL, 1998), uma incorporação de atos e significados (BELTING, 2013) que a tornam agente/sujeito por meio das práticas sociais que constituem processos de significação (MITCHELL, 1994). Não há uma "grande teoria" da imagem como prática, embora coexistam pesquisas e aportes que articulam bases empíricas e teóricas que se incorporam na concepção da maioria dos historiadores que tratam da cultura visual, estando presentes desde os trabalhos da história social da arte até as mais recentes obras de Serge Gruzinski (2006), Jean-Claude Schmitt (2007), Hans Belting (2014) compêndios e dossiês como os organizados por Charles Monteiro (2012), Ana Mauad e Marcos Lopes (MAUAD, LOPES, 2014), lara Lis Schiavinatto e Eduardo Costa (COSTA; SCHIAVINATTO, 2016) e Berbara e Conduru (2014) e tantos mais em atividade. Seu débito com uma perspectiva antropológica da constituição de sentidos e usos sociais dos artefatos e imagens é imenso, além da evidente influência dos estudos de cultura material que contemplam instituições variadas (museu, patrimônio, arquivo, estado, igrejas, etc.) ou formas e usos sociais fragmentados de artefatos e imagens.

A noção da imagem como prática social é funcional e tem sido combinada e refratada em relação a três outras: a biografia, o campo social e o dispositivo. A biografia da imagem é o conjunto de "situações provocadas por sua existência e ação no mundo social”, constituindo-se na sua trajetória, "como sujeito, objeto e agente da história" (MAUAD, 2016, p. 45). De uma perspectiva socioantropológica, é possível pensar o papel 
da imagem na constituição histórica dos diversos campos sociais. Existiriam modos de fazer socialmente compartilhados ou organizados de imagens, como, por exemplo, culturas pictóricas, culturas cinematográficas, culturas fotográficas, etc., ainda que nem sempre a existência de práticas de olhar signifique que estas tenham papel hegemônico nos campos sociais. Sem qualquer caráter prescritivo, a perspectiva historiográfica da imagem como prática acentua seus modos diversos de interação nos campos sociais organizados de sua produção - tais como a cultura pictórica italiana entre os séculos XIV e XVIII ou a cultura cinematográfica estadunidense desde 1907 - bem como sua participação mais ou menos transversal em campos sociais autônomos, tais como se observa no caso da cultura fotográfica, a qual frequentemente trabalha por meio de padrões de usos, leituras e comportamentos (KOZLOFF, 1979) desenvolvendo-se ao redor de práticas variadas (MAUAD, 2006, 2018), com uma mídia sem instituição própria. Nesse segundo caso, as imagens se inserem em outras matrizes de produção já existentes (imprensa, por exemplo) ou que surgiram depois dela (publicidade, o cinema, a televisão ou a web) (D'AUTILIA, 2012).

(3) A relação presença e a representação tornou-se uma questão. Se, na história cultural, a representação goza de ampla aceitação, para os Visual studies, a Sintomalogia ou a Bildwissenschaft, caiu em desconfiança. No avanço da virada linguística, a representação foi convertida em efeito do discurso. Mais tarde, com a história cultural, o conceito passou a significar o sistema de classificação e hierarquia compartilhadas socialmente (CHARTIER, 1991; RICOEUR, 2007). A cultura visual incorporou essa segunda acepção, mas considerando a representação como uma prática ou performance de significação incorporada ou indexada em artefatos ou fazeres visuais. As representações são usos e não efeitos de artefatos e discursos; potencializam aproximações e diferenciações por/como imagens. Contudo, é consenso que os usos representacionais de artefatos e dispositivos visuais não resumem ou explicam toda a interferência social e cognitiva por eles produzidas, as quais, advêm pelas várias perturbações que a presença visual/material causa no ambiente social; ou seja, não contemplam toda a iconicidade das imagens. A presença-imagem ativa uma potência temporal e afetiva que evidencia, ainda, a memória que as imagens acionam, as sobrevivências do passado e sua força disruptiva no presente. Destaca-se a dimensão dêitica da imagem de maneira que a presença 
demanda uma atitude diferente do historiador - como tentou polemizar Gumbrecht (2010) - de maneira a evidenciar a iconicidade como força histórica (ALLOA, 2012).

A partir desses pontos, desenvolveram-se propostas de tratamento das imagens a partir de matrizes já conhecidas da história da arte e também na história das imagens e que permitem aos historiadores reconstruções históricas. Aqui, destacamos apenas três: a arqueologia e a interconexão da iconologia com a antropologia das imagens.

(a) A arqueologia das imagens se tornou uma orientação metódica possível de trabalho se tomamos a chave teórica do dispositivo combinada com a noção de práticas sociais. Se o conceito de dispositivo de Michel Foucault foi central para a emergência dos estudos visuais ${ }^{26}$, a noção sofreu um sensível refinamento ${ }^{27}$. François Albera e Maria Tartajada (2010) deslocaram a noção de dispositivo, de uma concepção de tecnologias e técnicas que subjetivam e formatam os sujeitos, para uma de como os sujeitos formatam essas tecnologias por meio de diversos usos e aplicações cruzados e descontínuos. O dispositivo seria como um eixo de relações, contemplando toda coisa que é apresentada em frente a um espectador, junto com todos os elementos que compõem uma representação e que podem ser vistos e ouvidos. O dispositivo envolve o que se faz e o que mostram imagens e sons; existe quando um ou dois desses elementos estão envolvidos como condições de uma rede entre espectador, representação e maquinário e organizam um eixo de relações sociais, as quais podem ou não constituir um campo social organizado.

A análise do dispositivo implica no estudo das condições de possibilidades da construção de conhecimento (saberes) e sujeitos em uma dada situação histórica, uma vez que é uma forma concreta que mobiliza discursos e práticas na constituição do conhecimento e informação que circulam socialmente. O estudo histórico dos dispositivos é uma tentativa de construir a estratificação dos saberes e práticas sociais que tornaram possível que um dado conjunto de sujeitos se relacionasse com um dado conjunto de representações por meio de máquinas que transformam pessoas em

\footnotetext{
26 Notadamente nas obras de Jonathan Crary, Svetlana Alpers (1999), Tom Gunning (1991), Nicholas Mirzoeff (1999), entre outros.

27 Como já dito antes, Emmanuelle Alloa considera que, de certa forma, a virada icônica é uma arqueologia das imagens, "isto é, uma análise dos traços de imagens no seio da tradição e das suas operações de sentido, emboscada entre as linhas do texto" (ALLOA, 2012, p. 148).
} 
espectadores (ALPERS, 1999; ALBERA; TARTAJARA, 2010; CRARY, 1999; MIRZOEFF, 2018; PINOTTI; SOMAINI, 2016). A forma como os dispositivos surgem é heterogênea, emergindo do confronto entre discursos e suas condições históricas concretas e objetivas nos meios sociais implicados. O exercício da análise arqueológica, nesse sentido, frequentemente não demanda referências a Foucault ou Agamben, mas evidenciam um mesmo ato de problematizar sujeitos espectadores, podendo ser identificados em pesquisas das mais diversas filiações teóricas.

(b) A iconologia e a antropologia das imagens combinam as condições de possibilidades de emergência das imagens, os usos, práticas sociais e as diversas indexações e agenciamentos que permitem que os artefatos incorporem qualidades imateriais as quais, por vezes, conferem às imagens alguma forma ou desejo de vida (MITCHELL, 2005), as possibilidades de pesquisar as condições antropológicas de funcionamento e atuação das imagens permitem observar novas possibilidades de descrição da realidade histórica (BELTING, 2013, BREDEKAMP, 2015).

A iconologia seria, assim, "o estudo das imagens através das imagens e especialmente da interface entre linguagem e representação visual” (MITCHELL, 2015). Ela se ocupa dos tropos, figuras e metáforas bem como dos motivos gráficos e visuais, tanto com os gestos como com os espaços de aparição das imagens. Trata-se de uma heurística pós-Panosfky que se ocupa da relação entre imagens e linguagem, das imagens em suas migrações, o estatuto sócio-histórico das imagens mentais, fantasia e da memória, o estatuto teológico e político das imagens nos seus usos sociais, o papel cognitivo das imagens na configuração, elaboração e distribuição do conhecimento, a emergência de novas imagens e de novos conceitos de imagens.

(c) Como uma antropologia das imagens (BELTING, 2013), a iconologia é uma taxionomia da historicidade das maneiras diversas pelas quais as imagens migram e ocupam funções sociais, construindo condições de existência que demandam formas sociais específicas para sua manutenção, movimentam sujeitos e comunidades ao redor de princípios compartilhados, incorporando qualidades sociais que, sem elas, não funcionariam. A antropologia das imagens permite tratar da biografia das imagens, ou seja, abordar as suas trajetórias e as situações geradas por sua existência, produzindo um 
contexto que só é aquele porque ali consta um artefato visual que faz a realidade social interagir (MAUAD, 2016; MENESES, 2012).

A ideia de uma imagem constituir um ato implica em problematizar o fato dela estar relacionada a práticas variadas das quais incorpora qualidades e às quais adiciona possibilidades históricas (BREDEKAMP, 2016). A problematização da maneira como as imagens são animadas ou animam o ambiente permite rever as práticas sociais como articulação de crença, afeto e corporificação. Nela, evidencia-se a maneira como os tempos se combinam e refratam passados e presentes na memória das imagens (DIDIHUBERMAN, 2016), bem como as maneiras diversas como a realidade social se multiplica em diversas camadas por meio delas (GUIMARÃES, 2007; MENDONÇA, 2016).

\section{Ainda os traços, o tempo e a persistência do passado}

Considerando que o conhecimento histórico elabora a historicidade das experiências por meio do exercício analítico-narrativo e do tratamento metódico de fontes para constituição de orientações acionais públicas, após tudo exposto acima, chegamos ao ponto central do texto: a virada imagética parece ter três impactos propriamente historiográficos: (I) deslocamento da concepção da fonte histórica; (II) a reconstituição do papel da anacronia na construção de outra concepção de historicidade; (III) a reformulação da preocupação com a visualidade/visibilidade do passado.

(I) Paradigmas distintos da historiografia consideram que esta é construída e validada com/por documentos. A concepção historicista da fonte histórica, consagrada pela escola metódica francesa especificava a história como uma operação de "reviver" fatos por meio de seus "vestígios", os documentos, a partir do método da crítica histórica ${ }^{28}$. Os acontecimentos históricos seriam comprováveis por meio das fontes. $\mathrm{A}$ virada imagética, por sua vez, desafia a concepção de fonte convencional pelo fato de

\footnotetext{
${ }^{28}$ Nas palavras de Charles Seignobos e Charles Langlois (2016): “Os eventos do passado só são conhecidos pelos traços que foram preservados. Esses vestígios, é verdade, são observados diretamente pelo historiador, mas além disso, não há mais nada para observar; o que permanece é o trabalho do raciocínio que extrai, com a maior precisão possível, os fatos dos vestígios”. Concepções narratológicas da histórica também trabalham com essa categoria: "A história é uma narrativa de acontecimentos. Todo o resto deriva disso (...). Em nenhum caso, aquilo que os historiadores chamam de acontecimento é capturado diretamente ou por inteiro. Eles são capturados sempre indiretamente e em modo incompleto, por via de documentos ou testemunhos; digamos por meio di tekmèria, de traços" (VEYNE, 1973, p. 12-13).
} 
que há uma presença visual na frente do historiador, no presente da operação historiográfica, a qual intervém no conhecimento produzido a partir e com ela.

Debates relacionados à iconologia e aos estudos de história das práticas visuais apontam que o passado comprovável teria sido deslocado por um tempo em movimento no qual o passado que sobrevive na imagem e a presença visual do artefato criam outra relação com a operação historiográfica. Inaugura-se um nó heurístico ao qual Meneses (2012) propôs como solução dar atenção à natureza visual da fonte, entendendo-a como atuante na construção do passado por ela acessível, desde que se consiga estabelecer sua trajetória como corpo e artefato socialmente em relação. Ana Mauad (2016) explicita esse ponto como superação da epistemologia da prova por meio da consideração da imagem como parte viva do tecido social, tanto no passado como no presente no qual é problematizada.

O problema seria: fora da epistemologia da prova, em que campos se movem os historiadores? Se uma imagem "não deveria” ser tratada como uma fonte histórica “convencional”, como abordá-la29? A fonte histórica é, como dito acima, o núcleo de quase todos os paradigmas historiográficos e, a "metáfora dos vestígios", um recurso habitual na sua caracterização. Segundo Joseph Morsel (2016), tal metáfora esteve ligada a uma tradicional concepção de (sic) índice-impressão, do qual a pegada na areia, o traço deixado pelo homem, seria o paradigma ${ }^{30}$. Contra essa concepção, Morsel propôs a noção de sintoma e um paradigma sintomal.

\footnotetext{
29 Peter Burke (2017) tentou resolver este problema descartando a noção de documento, muito ligada à tradição escrita, ao usar a acepção jurídica de evidência aceitável, considerando as imagens como resultados de testemunhos oculares da história. Burke (2017) ocupa um lugar de epistemólogo a partir do gênero do manual historiográfico Testemunha ocular - texto generalista em muitos aspectos. Evita a acepção forte da antiga evidência histórica e busca uma acepção fraca da evidência aceitável, pensando a imagem como um ato de testemunho ocular, cuja produção deve ser reconstruída. Ora o documento é, em sentido estrito, um texto que vale para comprovar o cumprimento de uma ação jurídica, ajuntando-se como prova ao obedecer indispensavelmente regras determinadas. Trocando o termo evidência aceitável por documento, percebe-se em Burke a permanência da epistemologia da prova.

30 Podemos distinguir didaticamente com Bernardi e Guarracino (1996): restos são as fontes involuntárias, traço do passado que não foram intencionalmente predispostos para recordar eventos. Fontes são, no sentido estrito, traços voluntariamente predispostos das sociedades humanas em conservar suas lembranças. Documentos, originalmente, eram apenas textos escritos sujeitos ao escrutínio para determinar sua validade comprobatória, sendo produzidos intencionalmente. Obviamente são termos intercambiáveis.
} 
Segundo essa concepção, a presença da/na imagem articula outra grade de experiências, uma vez que a materialidade da fonte visual transforma a elaboração do discurso sobre a imagem como artefato. O que de fato está presente como imagem a deixaria apartada de um conceito semiótico de traço ou indício. A partir da virada icônica, se passaria a considerar que o que ocorre frente a uma imagem só o ocorre porque ela é um corpo material em cuja superfície aparece algo no agora. Se o indício marcaria o que falta (o passado), a imagem marcaria o que está diante do historiador como tempo mantido. O modelo mais condizente (sic), portanto, segundo Emmanuel Alloa (2016), seria tomar a imagem como sintoma, uma vez que esta demanda um corpo material em cuja superfície "algo" deve aparecer ${ }^{31}$. Os trabalhos de George Didi-Huberman (2016) seriam um modelo dessa sintomatologia (ALLOA, 2012), ou seja, uma concepção que trata a imagem como um cruzamento ou emaranhado de forças em uma proposta de história bem documentada, marcadamente descritiva do material empírico histórico, potencialmente intuitiva e abertamente metafórica.

Segundo Didi-Huberman, a identificação das forças e das formas relacionais na imagem entendida como conflagração que perturba os campos discursivos é própria do exercício de uma heurística a qual deve corresponder outra escrita da história (ALLOA; 2012; MORSEL, 2016; MOXEY, 2008). A escrita da história opera as imagens por meio da exploração de novas potencialidades e deve se apresentar em modalidade de conjectura subjuntiva, ou seja, tratar "da história no futuro do pretérito por meio de imagens condensadas de tempos" (MAUAD; 2016, p. 46).

Contudo, apesar desse aparato conceitual, permanece claro que, a rigor, a imagem não deixa de ser indício ao ser abordada como sintoma ${ }^{32}$; e as noções de traço, indício,

\footnotetext{
31 O interessante artigo de Joseph Morsel (2016) propõe um "paradigma sintomal” que implicaria em um ganho da cientificidade da historiografia, aproximando-a das disciplinas que estudam o presente (antropologia e sociologia) e afastando-a das "auxiliares" voltadas à "ressurreição do passado" (sic), como a psicanálise. $\mathrm{O}$ eco da tradição dos Annales se faz pela proposta da aproximação com as ciências sociais da parte de Morsel, que toma a sintomatologia como um outro paradigma. Morsel chama os "vestígios" de metáfora sem problematizar o que seria uma metáfora e como ela funcionaria nos textos historiográficos durante os séculos XX e XXI; e pressupõe uma semântica do vestígio na historiografia como algo negativo e ligado irremediavelmente à "ressurreição" do passado, incorrendo em generalizações duvidosas.

32 A história das coleções, do colecionismo e dos usos de artefatos que foram transformados em signos/ícones do passado (fósseis, fragmentos, ruínas, fotos) demonstra que estes oscilaram entre diversos estatutos históricos icônicos e semióticos. Cf. POMIAN, 1989; GINZBURG, 1991; BREDEKAMP, 2015; GUIMARÃES, 2007; GEIMER, 2016.
} 
ruína, marca e sintoma são aparentadas de uma afecção/semântica que precisa de ulterior refinamento, uma vez que compõem uma constelação nocional ou conceitual cuja epistemologia não é a da prova. Recorde-se, por exemplo, que a emergência do paradigma indiciário (GINZBURG, 1991) abriu a possibilidade da construção de uma epistemologia fragmentada do traço, a qual, do ponto de vista da historiografia, ocupa uma posição transversal em relação à heurística da fonte histórica como vestígio/prova do passado. No ensaio de Ginzburg (1991) sobre os sinais, em especial, o indício é uma marca à espera de uma narração, cujo potencial se realiza no colocar em relação algo com outra coisa - um signo como promessa. Como evidencia Agamben (2008, p. 69-70), o indício de Ginzburg é uma assinatura ou inscrição (ato de meter em relação) e é sempre dotado de temporalidade flexível interconectada com as subjetividades, os objetos, os detalhes, os eventos e as realidades com os quais é posto em relação. As noções imagem, traço, índice e sintoma são qualidades não-excludentes - ou exclusivas - nas quais se movem as imagens e as tornam historicamente significativas, devendo fazer parte da análise histórica de seu funcionamento ${ }^{33}$. De tudo, tira-se que a imagem como fonte/sintoma demanda outra forma de perguntar e de narrar que considere as múltiplas combinações históricas dos eventos e sujeitos aos quais elas podem ser associadas.

(II) O mais badalado problema que adveio dos novos estudos de imagens e da virada visual foi a reabilitação do debate do anacronismo nos novos modelos de temporalidade e historicidade. Os estudos sobre imagens e memória (BENJAMIN, 1985, 2009; ROSSI, 2004; YATES; 2007; WARBURG, 2010) já haviam evidenciado que um aspecto central da presença de imagens é a alteração da relação (individual e social) com o tempo, com a temporalidade e com a história. Da década de 1970 em diante, tem-se chamado atenção à força das imagens na elaboração da temporalidade e da historicidade, frequentemente em forte diálogo com os estudos das mídias, indagando sempre sobre a persistência da história (SOBCHACK, 1995).

Tempo e historicidade não são questões novas: os debates sobre o que foi chamado de presentismo remontam às obras de Benedetto Croce (2006) e Robin Collingwood (1981); assim como o paradigma historiográfico marxista, por exemplo, tem

\footnotetext{
${ }^{33}$ Seguindo a apropriação de Gayatri Spivak da obra de Derrida, Mitchell (1994) considera que a inscrição e o traço gráfico, o arquivo da pré-história da escritura, funciona como um processo indicial/icônico.
} 
uma longa tradição de reflexão filosófica sobre a historicidade capitalista e os impactos da aceleração produtiva na cultura, o que na historiografia manifestou-se na preocupação com a construção social do tempo na história social inglesa ${ }^{34}$, presente também na historiografia francesa - destaque-se Fernand Braudel (2007a) e sua reflexão sobre os três tempos. Também a Begriffsgeschichte, a "história dos conceitos" alemã (JASMIN; FERES JR., 2007), a reflexão hermenêutica de Paul Ricoeur (2007) e os debates sobre os regimes de historicidade (HARTOG, 2014) reorganizaram o entendimento da relação da história com o tempo no final do século XX e início do XXI.

Mas qual a especificidade da discussão entre imagem e tempo frente a este quadro? Esta surgiu de algumas preocupações, cada qual com sua trajetória singular: a (a) superação da dicotomia entre artes do tempo (escritas) e artes do espaço (visuais), herdada do Lacoonte, de Lessing, e ainda importante na filosofia e história da arte (BOEHM, 1981; MITCHELL, 1980, 1986); (b) a relação entre imagem e memória que remontam aos trabalhos pioneiros de Frances Yates (2007), Paolo Rossi (2004) e às sucessivas retomadas de Aby Warburg e Walter Benjamin por inúmeras disciplinas (SETTIS, 1985; BUCK-MORSS, 1991, DIDI-HUBERMAN, 2016); (c) a composição do tempo pela pintura histórica, fotografia e as mídias audiovisuais (CLARK, 2007; COLI, 2010; SOBCHACK, 1995); (d) a constituição de temporalidade pública nos lugares e espaços de memória (ASSMAN, 2011; NORA, 1993), colecionismo (POMIAN, 1989), patrimônio (CHOAY, 2001), museus (MENESES, 1992; SANDBERG, 1995)35, monumento e antimonumento (HUYSSEN, 2014; PINOTTI, 2014). Perceba-se que um paradigma difuso da memória, pela qual o passado se apresenta como imagem, tornou-se uma chave para explorar a relação com o tempo produzida em/por imagens. A partir de meados dos anos 1990, Georges Didi-Huberman (2016), em especial, tornou-se um grande propagador da anacronia das imagens e da tematização da memória das imagens. A anacronia não seria,

\footnotetext{
34 Não se pode esquecer que Time, Work-Discipline, and Industrial Capitalism, artigo famoso de Edward Thompson (1998) sobre a economia popular do tempo era de 1967. No diálogo com a antropologia, o tempo e a temporalidade como formas de produção comunitária e simbólica estiveram presentes na história social da cultura.

$35 \mathrm{Na}$ historiografia, a reação à hipertrofia da memória, na segunda metade do século XX, gerou a necessidade de demarcar fronteiras disciplinares entre história/memória. Autores como Jacques Le Goff (1994), Pierre Nora, Jörn Rüsen (2015), Ulpiano Meneses (1992) investiram nessa distinção. Sobre a disciplinarização da memória pela historiografia Cf. GONÇALVES, 2014; SANTIAGO JR., 2015.
} 
nesse âmbito, o "pecado original” do historiador, e a potência da memória reconduziria o conhecimento sobre o passado a uma compreensão dos cruzamentos de tempos na operação historiográfica.

Não se trata, hoje, de tomar o conhecimento histórico como resultado apenas do momento de sua produção ou projetar no passado as categorias do presente, mas de entender como ambos se interpenetram, uma vez que se pressupõe que o passado sobrevive junto ao presente com o qual se conflagra; é ativado pelas experiências atuais, é alterado pelo olhar dos sujeitos da atualidade e modifica a atualidade. Deslocando o problema de Didi-Huberman, para quem a anacronia ${ }^{36}$ é a potência fundamental do saber que a imagem produz, Keith Moxey (2013) postula que a heterocronicidade das imagens é a matéria-prima do trabalho historiográfico, o qual atenta para e produz heterocronias. 0 tempo histórico é construído como experiência social de forma diferenciada junto às imagens e, uma vez que existe uma memória própria delas, a migração de seus aspectos em múltiplos suportes gera diversas temporalidades por meios de seus corpos. Como traços do que foi e sintomas do que continua sendo, as imagens rearticulam possibilidades de historicidades a serem construídas como escrita e/ou visualização da história.

(III) Finalizamos este texto apontando o problema da visualidade e visibilidade do passado, a dimensão pública da história e sua relação com as formas de construção do passado como o museu, o arquivo, o monumento e o patrimônio. A relação do olhar com a visibilização do passado, retomada por Manoel Guimarães (2007) a partir dos problemas da virada imagética, já havia sido realçada por Krzyśztof Pomian (1989, p. 34), a respeito de como determinados artefatos se tornavam semióforos, sinais do "muito distante no tempo", ou seja, do passado invisível. A ideia da historiografia como um olhar, uma maneira de "dar forma ao passado", construir-lhe um quadro, ou uma dramaturgia, é antiga e já estava presente na obra de Johann Huizinga (2013, p. 12). Também a ideia da

\footnotetext{
36 Desde Benedetto Croce (2006) e Collingwood (1981) se reflete sobre o problema do papel do historiador e da cultura do presente na elaboração do conhecimento histórico. A rigor, as mais radicais teorias narratológicas postulavam que o trabalho do historiador só poderia ser anacrônico. Nesse sentido, a discussão sobre anacronia não é nova e sua recente reabilitação via estudos da imagem e da cultura visual permanece um campo de reflexões em aberto.
} 
história como produtora de fotos/imagens era uma das bases das constelações conceituais de Walter Benjamin (2009) ou da reflexão histórica-historiográfica de Sigfried Kracauer (2010). Todos pressupunham que a historiografia articula imagens e metáforas visuais, constitui um olhar e elabora, por meio de enunciados e textos, cenas ou quadros do passado, questão que foi recentemente retomada por Frank Ankersmit (2012).

Além da historiografia, outras instituições problematizaram a visibilidade por meio da visualização do passado. Como demonstraram Meneses (2004) e Mendonça (2006, 2016), foi a partir dos problemas do olhar, da visão, dos modos de ver que emergiu um campo interdisciplinar de pesquisa de cultura visual. Trata-se da constatação do olhar como procedimento não somente psico-fisiológico. As imagens são simultaneamente consideradas como produtos \& meios, tecnologias da comunicação \& pensamento resultantes da ação humana. Abandonou-se a ideia do olho como fonte da visão, do olhar como processo fisiológico e pensou-se na visão como um conjunto de técnicas/performances que usam suportes e dispositivos articulados socialmente. O olhar e os modos de ver passaram a ser historicizáveis e passou-se a compreender que compunham as formas como as sociedades visualizaram/organizaram seus passados e constituíram conhecimento histórico, seja em formas institucionais (museus, arquivos, academias, coleções) ou não-institucionais (práticas fotográficas, cinematográficas, literárias, videográficas, artísticas, televisivas e tantas outras formas visuais).

Como objeto da pesquisa historiográfica, o olhar é um campo de pesquisas. Existem elementos não-discursivos presentes na construção pública do passado que são articuláveis em instituições que lidam com a visibilidade do passado, como o museu ou o patrimônio cultural, transformando, por vezes, coisas não-icônicas (fragmentos) em imagens, bem como articulando imagens já existentes como sinais do mundo pretérito (monumentos históricos, por exemplo) em cenografias (GUIMARÃES, 2007). Quando se aborda o tema específico da história pública ou dos usos do passado em instituições ou dispositivos, emerge o papel das imagens na elaboração da visualidade e visibilidade do passado tanto fora como no próprio discurso historiográfico.

Surge o problema, postulado por Peter Geimer (2015, 2018), de saber quais as estratégias de produção das várias formas de evidências visuais daquilo que não existe 
mais, que fazem parte do passado e da história, enfim, dos modos pelos quais as imagens participam da constituição dos diversos tipos de evidências icônicas e saberes daquilo que é chamado de histórico (PINOTTI; SOMAINI, 2016, p. 30) nas sociedades de antes e do agora. A antropologia das imagens e a iconologia fornecem meios para decifrar a composição imagética do discurso historiográfico e das formas públicas de história. A história da historiografia e o estudo dos usos públicos do passado como produção da materialidade/visualidade/visibilidade do passado seriam, assim, tanto um campo de pesquisa como de atuação do historiador, pois apontam também para a constituição de formas diversas do que Valdei Lopes chama de curadoria do profissional de história na esfera pública, ou seja, ações "na promoção, seleção, edição e reapresentação de histórias socialmente distribuídas e compartilhadas" (LOPES, 2017, p. 213), participando junto das comunidades na "comunicação, circulação e democratização do direito à história" (LOPES, 2017, p. 212).

A conclusão lógica, evidentemente, é que as mídias também são produtoras da visibilidade do passado e que práticas fotográficas, cinematográficas, televisivas, videográficas, além de games, infografia (em suas possibilidades variadas como sites, redes sociais, plataformas interativas) estão entre as mais poderosas forças contemporâneas para construção de fatos e persistência do passado nas sociedades atuais. Torna-se urgente pensar o uso público do passado por imagens como um agenciamento disputado em diversos campos culturais, produzindo disciplinar ou ludicamente o passado vinculado a grupos de poder. Consolida-se o problema do historiador para além do ensino, que atua em exposições ou narrativas visuais em geral, em espaços não-historiográficos ou de ensino indireto, remetendo-lhes a funções novas. A virada visual termina por encontrar a história pública.

\section{Considerações finais}

Os pontos acima estão interligados. Indicam como, atualmente, as viradas imagéticas articulam veredas que ainda estão em questão. Dizem respeito à prática historiográfica, e, claro, à teoria da história e à história da historiografia, mas também às diversas curadorias possíveis na produção do passado público. A nosso ver, esse último 
aspecto é o mais importante que permite pensar a persistência do passado nas sociedades em diálogo com a esfera pública.

$\mathrm{Na}$ atualidade, a visualidade da história é construída por meio de recursos visuais multimidiáticos e instaura um modelo de temporalidade que tem nas performances icônicas um fator fundamental para que passados persistam e alguns presentes se imponham. Urge compreender o problema das tradições históricas que são veiculadas por meios diversos (em nosso tempo, audiovisuais e digitais). Talvez assim possamos, por exemplo, entender temas de difícil trato, como a maneira como a tradição política autoritária brasileira persistiu como narrativa público-midiática e se tornou uma das bases da crise democrática na qual vivemos.

O historiador, um dos guardiões do passado, perturba memórias, mas além de produzir compreensão do passado coletivo, pode atuar pública e interinstitucionalmente (em museus, arquivos, assessorias, etc.) mediando a relação de espectadores/leitores e/ou alunos - porque, como historiadores, no Brasil, somos professores e curadores com os passados midiaticamente produzidos. As imagens são conflagrações de histórias e o passado é sempre cobiçado pelo "inimigo", sabedor de sua função social. Ele, o “inimigo", como se sabe, não tem cessado de vencer...

\section{Referências}

AGAMBEN, Giorgio. Signatura rerum: sul método. Torino: Bollati Boringhieri, 2007.

ALBERA, François; TARTAJADA, Maria. Cinema Beyond film: media, epistemology in the modern era. Amsterdan: Amsterdan University Press, 2010.

ALLOA, Emanuele. Iconic turn: alcune chiavi di svolta. Lebenswelt, Milano, n. 2, p. 144-159, 2012.

ALPERS, Svetlana. A arte de descrever. São Paulo: EDUSP, 1999. 
ALBUQUERQUE JR., Durval M. História a arte de inventar o passado. São Paulo: EDUSC, 2004.

ANKERSMIT, Frank. Enunciados, textos y cuadros. In: Giro lingüístico, teoria literaria y teoria histórica. Buenos Aires: Prometeo, 2012.

ASSMANN, Aleida. Espaços da recordação. Campinas, SP: EDUNICAMP, 2011.

BATESON, Gregory; MEAD, Margareth. Balinese character: a photographic analysis. New York: Wilbur Editor, 1942.

BAXANDALL, Michael. 0 olhar renascente: pintura e experiência social na Itália da renascença. Rio de Janeiro: Paz e Terra, 1991.

BENJAMIN, Walter. A imagem de Proust. In: Obras Escolhidas. vol. 1. São Paulo: Brasiliense, 1985.

BENJAMIN, Walter. Passagens. Belo Horizonte: EDUFMG, 2009.

BELTING, Hans. Antropologia delle immagini. Roma: Carocci, 2013.

BELTING, Hans. Facce. Milano: Carocci, 2014.

BELTING, Hans. Image, medium, body: a new approach to Iconology. Critical Inquiry, v. 31, n. 2, p. 302-319, 2005.

BERBARA, Maria; CONDURU, Roberto, SIQUEIRA, Vera Beatriz (orgs.). Conexões: ensaios de história da arte. Rio de Janeiro: EDUERJ, 2014. p. 19-46.

BERNARDI, Alberto; GUARRACINO, Scipione (orgs.). Dizionario di storiografia. Milano: Bruno Mondadori, 1996.

BESANÇON, Alain. A imagem proibida. Rio de Janeiro: Betrand Brasil, 1997.

BETTETINI, Maria. Control le immagine: la radici dell'iconoclastia. Laterza: Roma-Bari, 2013. 
BLUMENBERG, Hans. Paradigmi per una metaforologia. Milano: Raffaelo Cortina, 2018.

BODEI, Remo. Introduzione. In: BLUMENBERG, Hans. La leggibilità del mondo: il libro come metafora della natura. Bologna: II Mulino, 1989.

BOEHM, Gottfried. II ritorno delle immagine. PINOTTI, Andrea; SOMAINI, Antonio (orgs.). Teorie dell'immagine: il dibattito contemporaneo. Milano: Raffaello Cortina Editore, 2009a. p. 39-72.

BOEHM, Gottfried. Immagine e tempo. In: DOTTORI, R.; KUNKLER, H. (orgs.). Estetica e ermeneutica. Napoli: Pironti, 1981, p. 121-134.

BOEHM, Gottfried. La svolta iconica. Roma: Meltemi, 2009b.

BRAUDEL, Fernand. História e ciências Sociais: a longa duração. In: Escritos sobre a História. São Paulo: Perspectiva, 2007a. p.41-78.

BRAUDEL, Fernand. O modelo italiano. São Paulo: Cia das Letras, 2007b.

BREDEKAMP, Horst. A neglected tradition? Art history as 'Bildwissenschaft'. Critical Inquiry, v. 29, n. 1, p. 418-428, maio 2003.

BREDEKAMP, Horst. Immagine che ci guardano: teoria dell'atto iconico. Milano: Cortina, 2015.

BREDEKAMP, Horst. Nostalgia dell'antico. Milano: Il Saggiatore, 2016.

BRENNAN, Teresa; JAY, Martin (orgs.). Vision in context. New York: Routleged, 1996.

BRYSON, Norman. Tradition and desire. Cambridge: Cambridge University Press, 1987.

BUCK-MORSS, Susan. The dialectis of seeing. Cambridge: The MIT Press, 1991.

BURKE, Peter. Testemunha ocular: o uso de imagens como evidência histórica. São Paulo: Edittora da UNESP, 2017.

CARDOSO, Ciro; MAUAD, Ana Maria. História e imagem: os casos do cinema e da fotografia. In: CARDOSO, Ciro; VAINFAS, Ronaldo (orgs.). Domínios da história: ensaios de teoria e metodologia. Rio de janeiro: Editora Campus, 1997. 
CARDOSO, Rafael. A história da arte e outras histórias. Cultura visual, Salvador, n. 12, p. 105-113, out. 2009.

CARVALHO, Vânia. Gênero e artefato. São Paulo: EDUSP, 2004.

CARVALHO, Vânia; LIMA, Solange Ferraz de. Fotografia e cidade: da razão urbana à lógica do consumo: álbuns de São Paulo (1887-1954). Campinas: Mercado de Letras, 1997.

CARVALHO, Vânia; LIMA, Solange Ferraz de. São Paulo antigo, uma encomenda da modernidade: as fotografias de Militão nas pinturas do Museu Paulista. Anais do Museu Paulista, São Paulo, v. 1, p. 147-174, 1993.

CHARTIER, Roger. O mundo como representação. Estudos avançados, São Paulo, v. 5, n. 11, p. 173-191, 1991.

CHOAY, Françoise. Alegoria do Património. São Paulo: Cortez, 2001.

CLARK, T. J. Modernismos. São Paulo: Cosac \& Naify, 2007.

COLI, Jorge. O corpo da liberdade. São Paulo: Cosac \& Naify, 2010.

COLI, Jorge. A pintura e o olhar sobre si: Victor Meirelles e a invenção de uma História visual no século XIX brasileiro. In: FREITAS, M. C. (org.). Historiografia Brasileira em Perspectiva. São Paulo: Contexto, 1998. v. 1, p. 375-404.

COLI, Jorge. Pela implantação de graduações em história da arte nas universidades brasileiras. In: RIBEIRO, M. A.; RIBEIRO, M. I. B. (orgs.). COLÓQUIO DO COMITÊ BRASILEIRO DE HISTÓRIA DA ARTE, 26., 2007, Belo Horizonte. Anais [...] Belo Horizonte: C/arte, 2007.

COLLINGWOOD, R. G. A ideia de história. Portugal: Presença, 1981.

COMETA, Michele. La scrittura delle immagine: letteratura e cultura visuale. Milano: Raffaelo Cortina Editore, 2012.

COMETA, Michele. Prefazione all'edizione italiana. In: MITCHELL. William James Thomas. Pictorial turn: saggi di cultura visual. 2. ed. Milano: Raffaello Cortina Editore, 2017. p. 9-40.

CONDURU, Roberto. Ensaios excêntricos: ensinando e escrevendo uma história da arte 
de alcance mundial a partir da Universidade do Estado do Rio de Janeiro. Concinnitas, Rio de Janeiro, ano 17, v. 01, n. 28, p. 273-280, set. 2016.

COSTA, Eduardo; SCHIAVINATTO, lara Lis (orgs.). Cultura visual e história. São Paulo: Annablume, 2016.

CROCE, Benedetto. História como história da liberdade. Rio de Janeiro: Topbooks, 2006.

CRARY, Jonathan. Técnicas do observador. São Paulo: Contraponto, 2012.

D’AUTILIA, Gabriele. Storia della fotografia in Italia. Milano: Euinaudi, 2012.

DEBRAY, Régis. Vida e morte da imagem. Petrópolis: Vozes; 1993.

DIDI-HUBERMAN, George. Beato Angelico: figure del dissimile. Milano: Abscondita, 2014.

DIDI-HUBERMAN, George. Diante do tempo: história da arte e a anacronia nas imagens.

Belo Horizonte: EDUFMG, 2016.

DIDI-HUBERMAN, George. O que vemos, o que nos olha. São Paulo: editora 34, 1998.

DIDI-HUBERMAN, George. A pintura encarnada. São Paulo: EDUNIAFESP, 2013.

DIKOVITSKAYA, Margaret. Visual culture. Cambridge: The MIT Press, 2006.

FABRIS, Annateresa (org.). Fotografia: usos e funções no século XIX. São Paulo: EDUSP, 1998.

FERNANDES, Cassio. Jacob Burckhardt e Aby Warburg: da arte à civilização do renascimento. Locus, Juiz de Fora, v. 12,n. 1, p. 127-143, 2006.

GARIN, Eugenio. O zodíaco da vida. Lisboa: editora Estampa, 1987.

GEIMER, Peter. Inadverted images: a history of photographic apparitions. Chicago: University of Chicago Press, 2018.

GEIMER, Peter. Photography as a "space of experience": on the retrospective legibility of historic photographs. Getty Research Journal, Chicago, n. 7, p. 97-108, jan. 2015. 
GELL, Alfred. Art and agency: an anthropological theory. Oxford: Oxford University Press, 1998.

GINZBURG, Carlo. Representação: a palavra, a ideia, a coisa. In: OLHOS de madeira: nove reflexões sobre a distância. São Paulo: Companhia das Letras, 2001. p. 85-103.

GINZBURG, Carlo. Sinais: raízes de um paradigma indiciário. In: Mitos, emblemas, sinais. São Paulo: Cia das Letras, 1991.

GOODY, Jack. A domesticação do pensamento selvagem. Petrópolis: Vozes; 2012.

GRUZINSKI, Serge. A guerra das imagens: de Cristovão Colomobo a Blade Runner (14922019). São Paulo: Cia das letras, 2006.

GUIMARAES, Manoel Luiz Salgado. Vendo o passado: representação e escrita da história. Anais do Museu Paulista, São Paulo, v.15, n. 2, p.11-30, dez 2007.

GUMBRECHT, Hans Ulrich. A produção da presença: o que o sentido não consegue transmitir. Rio de Janeiro: Contraponto, 2010.

GUNNING, Tom. D W Griffith and the origins of American narrative film. Urbana: University of Illinous Press, 1991.

HARTOG, François. Regimes de historicidade: presentismo e experiências do tempo. Belo Horizonte: Autêntica, 2014.

HUIZINGA, Johann. La scienza storica: il suo valore, la sua attualità. Milano: edizione Res Gestae, 2013.

HUNT, Lynn (org.). A nova história cultural. 3 ed. São Paulo: Martins Fontes, 2001.

HUYSSEN, Andreas. Culturas do passado-presente. Rio de Janeiro: Contraponto, 2014.

HILL, Christopher. Origens intelectuais da revolução inglesa. São Paulo: Martins Fontes, 1992.

FERES JR., João; JASMIN, Marcelo (orgs.). História dos conceitos: diálogos transatlânticos. Rio de Janeiro: Editora da PUC, 2007.

JENKS, Chris (ed.). Visual culture. London/New York: Routledge, 1995. 
KAUFMANN, Thomas DaCosta. Reflexões sobre história da mundial. In: BERBARA, Maria; CONDURU, Roberto, SIQUEIRA, Vera Beatriz (orgs.). Conexões: ensaios de história da arte. Rio de Janeiro: EDUERJ, 2014. p. 19-46.

KEMP, Martin. The science of art. Yales: Yale University Press, 1990.

KERN, Maria Lúcia. A imagem visual na nova história e história da arte. Revista Porto Arte, Porto Alegre, v. 7, n. 13, p. 97-109, nov. 1996.

KERN, Maria Lúcia. Historiografia da arte: revisão e reflexões face à arte contemporânea. Revista Porto Arte, Porto Alegre, v. 13, n. 22, p. 124-135, maio 2005.

KOSSOY, Boris; CARNEIRO, M. L. T. O olhar europeu: o negro na iconografia brasileira do Século XIX. 1. ed. São Paulo: Edusp, 1994.

KOZLOFF, M. Photography and fascination. Danbury: Addison House, 1979.

KRACAUER, Siegfried. Historia: las últimas cosas antes de las últimas. Buenos Aires: Las Cuarenta, 2010.

LANGLOIS, Charles, SEIGNOBOS, Charles. Introdução aos estudos históricos. Lisboa: Patola Livros, 2017.E-book.

LARA, Silvia. Fragmentos setecentistas. São Paulo: Cia das Letras, 2007.

LIMA, Valéria. J. B. Debret: historiador e pintor. Campinas, SP: Editora da UNICAMP, 2007.

LLOYD-JONES, V. P.; BLAIR, Worden (orgs.). History \& imagination: essays in honor of H. R. Trevor-Roper. Londres: Gerald Duckworth \& Co. Ltd., 1981.

LOPES, Valdei Araújo. O Direito à História: o(a) historiador(a) como curador(a) de uma experiência histórica socialmente distribuída". In: GUIMARÃES, Géssica; BRUNO, Leonardo; PEREZ, Rodrigo (orgs.). Conversas sobre o Brasil: ensaios de crítica histórica. Rio de Janeiro: Autografia, 2017. p. 191-216.

MAUAD, Ana Maria. Poses e flagrantes. Rio de Janeiro: EDUFF, 2008. 
MAUAD, Ana Maria. Imagem e auto-imagem do império. In: ALCENASTRO, Luiz Felipe de Alencastro. (org.). História da vida privada no Brasil império: a corte e a modernidade nacional. São Paulo: Cia das Letras, 1997.

MAUAD, Ana Maria. Imagens em fuga: considerações sobre espaço público visual no tempo presente. Tempo e argumento, Florianópolis, v. 10, p. 252-285, 2018.

MAUAD, Ana Maria. Sob o signo da imagem: a produção da fotografia e o controle de códigos de representação social da classe dominante, no Rio de Janeiro, na primeira metade do século XX. 1990. Tese (Doutorado em História) - Universidade Federal Fluminense, Niterói, 1990.

MAUAD, Ana Maria. Sobre as imagens na história, um balanço de conceitos e perspectivas. Revista Maracanan, Rio de Janeiro, v. 12, n. 14, p. 33-48, jan./jun. 2016.

MAUAD, Ana Maria; LOPES, Marcos Felipe de Brum. Imagem, história e ciência. Boletim Museu Paraense Emílio Goeldi, Belém, v.9, n.2, p. 283-286, 2014.

MENDONÇA, Paulo Knauss. Aproximações disciplinares: arte, historia, imagem. Anos 90, Porto Alegre, v. 15, n. 28, p.151-168, dez. 2008.

MENDONÇA, Paulo Knauss. Imaginária urbana e poder simbólico: escultura pública no Rio de Janeiro e Niterói. 1998. Tese (Doutorado em História) - Universidade Federal Fluminense, Niterói, 1998.

MENDONÇA, Paulo Knauss. No domínio dos acervos: história e as práticas do olhar. Revista Maracanan, Rio de Janeiro, v. 12, n. 14, p. 12-24, jan./jun. 2016.

MENDONÇA, Paulo Knauss. O desafio de fazer histórias com imagens: arte e cultura visual. ArtCultura, Uberlândia, v. 8, n. 12, p. 97-115, jan./jun. 2006.

MENEGUELLO, Cristina. Da ruína ao edifício. São Paulo: Annablume, 2008.

MENESES, Ulpiano T. B. de. A história, cativa da memória? Para um mapeamento da memória no campo das ciências sociais. Revista do Instituto de Estudos Brasileiros, São Paulo, n. 34, p. 9-24, dez 1992.

MENESES, Ulpiano T. B. de. Fontes visuais, história visual, cultura visual. Revista brasileira de história, São Paulo, v. 23, n. 45, p. 11-36, 2004. 
MENESES, Ulpiano T. B. de. História e imagem: iconografia/iconologia e além. CARDOSO, Ciro; VAINFAS, Ronaldo. Novos domínios da história. Rio de Janeiro: Civilização Brasileira, 2012, p. 243-261.

MIRZOEFF, Nicholas. An introduction to visual culture. London/New York: Routledge, 1999.

MIRZOEFF, Nicholas. Come vedere il mondo. Cremona: Johan e Levi, 2018.

MITCHELL, William John Thomas Iconology. Chicago: University of Chicago Press, 1986.

MITCHELL, William John Thomas Image Science: iconology, visual culture and media aesthetics. Chicago: The University of Chicago Press, 2015.

MITCHELL, William John Thomas Picture theory: essays on verbal and visual representation. Chicago: The University of Chicago, 1994.

MITCHELL, William John Thomas (org.). The language of images. Chicago: University of Chicago Press, 1980.

MITCHELL, William John Thomas (org.). What do pictures want? Chicago: University of Chicago Press, 2005.

MONTE, Maria Giuseppina di; MONTE, Michele di (org.). Introduzione. In: BOEHM, Gottfried. La svolta iconica. Roma: Meltemi, 2009. p. 7-36.

MONTE, Michele. Pre-scritto alla logica di uma scienza delle immagini. Lebenswelt, Milano, n. 2, p. 202-218, 2012.

MONTEIRO, Charles (org.). Fotografia, história e cultura visual: pesquisas recentes. Porto Alegre: EDIPUC, 2012.

MORETTIN, Eduardo. Humberto Mauro, cinema, história. São Paulo: Alameda, 2013.

MORSEL, Joseph. Traces? Quelles traces? Réflexions pour une historie non passéiste.

Revue historique, Paris, n. 680, v. 4, 2016.

MOXEY, Keith. Contemporaneity's heterochronicity. In: VISUAL time: the image in History. Duke: Duke UJniversity, 2013. p. 37-51. 
MOXEY, Keith. Visual studies and iconic turn. Journal of Visual Culture, Montreal, n. 7, v. 2, p. 131-146, ago 2008.

NORA, Pierre. Entre história e memória: a problemática dos lugares. Projeto História, São Paulo, n. 10, p. 7-28, 1993.

PESAVENTO, Sandra Jatahy. História cultural: experiências de pesquisa. Porto Alegre: Ed. UFRGS, 2003.

PINOTTI, Andrea. Antitotalitarismo e antimonumentalità: un'elettiva affinità. In: PIRETTO, Gian Pietro. (org.). Memorie di pietra: i monumenti delle dittadure. Milano: Raffaelo Cortina Editore, 2014. p 17-34.

PINOTTI, Andrea; SOMAINI, Antonio (orgs.). Teorie dell'immagine: il dibattito contemporaneo. Milano: Raffaello Cortina Editore, 2009. p. 9-38.

PINOTTI, Andrea; SOMAINI, Antonio (orgs.). Cultura visuale: imagine, sguardo, media, dispositivi. Milano: Einaudi, 2016.

POMIAN, Krzyśztof. Collezionisti, amatori e curiosi: Parigi-Venezia XVI-XVIII secolo. Milano: Il Saggiatore, 1989.

RICOEUR, Paul. A memória, a história, o esquecimento. Campinas, SP: EDUNICAMP, 2007.

ROSSI, Paolo. A chave universal. São Carlos: EDUSC, 2004.

RÜSEN, Jorn. Jörn Rüsen e o ensino de história. Curitiba: EDUFPR, 2010.

RÜSEN, Jorn. Teoria da história. Curitiba. Editora UFPR, 2015.

SALGUEIRO, Valéria. Vistas urbanas nos álbuns ilustrados por viajantes europeus do século XIX. Tempo, Rio de Janeiro, v. 4, p. 103-123, 1997.

SAMAIN, Etienne. Quando a fotografia (já) fazia os antropólogos sonharem: o jornal La Lumière (1851-1860). Revista de antropologia, São Paulo: USP, v. 44, n. 2, p.89-126, 2001. 
SANDBERG, Mark. Effigy and narrative: looking into the 19th Folk Museum. In: CHARNEY, Leo; SCHWARCZ, Vanessa (orgs.). Cinema and the invention of modern life. Los Angeles: University of California Press, 1995. p 320- 360.

SANTIAGO JR., Francisco das C. F. A virada e a imagem: história teórica do pictorial/iconic/visual turn e suas implicações para as humanidades. Anais do Museu Paulista, São Paulo, v. 27, n. 1, p. 1-51, abr. 2019.

SANTIAGO JR., Francisco das C. F. Dos lugares de memória ao patrimônio: emergência e transformação da 'problemática dos lugares'. Projeto História, São Paulo, n. 52, p. 245279, jan./abr. 2015.

SCHIAVINATTO, Iara L. F.. Pátria coroada: o Brasil como corpo político autônomo (17801831). São Paulo: Unesp, 1999. p.91-106.

SCHIAVINATTO, Iara Lis F.; ZERWES, Erika. Cultura visual: imagens na modernidade. São Paulo: Cortez, 2019.

SCHMITT, Jean-Claude. $O$ corpo das imagens: ensaios sobre a cultura visual na Idade Media. São Carlos, SP: EDUSC, 2007.

SCHVARZMAN, Sheila. Humberto Mauro e as imagens do Brasil. São Paulo: Hucitec, 2004.

SCHWARCZ, Lilian Moritz. O sol do Brasil. São Paulo: Cia das Letras, 2008.

SCHWARCZ, Lilian Moritz. As barbas do imperador: D. Pedro II. São Paulo: Cia das Letras, 1998.

SETTIS, Salvatore. Warburg continuatus: descrizione di una biblioteca. Quaderni storici, Bologna, v. 20, n. 58, p. 5-38, abril 1985.

SLENES, Robert. As provações de um Abraão africano: a nascente nação brasileira na Viagem alegórica de Johann Moritz Rugendas. Revista de história da arte e arqueologia, Campinas, n. 2, p. 271-96, 1995.

SOBCHACK, Vivian (org.). The persistence of history: cinema, television and modern event. New York: Routledge, 1995.

THOMPSON, Edward. Costumes em comum. São Paulo: Cia das Letras, 1998. 
VERNANT, Jean-Pierre. Da presentificação do invisível à imitação da aparência. In: Entre mito e política. 2 ed. São Paulo: EDUSP, 2002. p. 295-308.

VEYNE, Paul. Come si scrive la storia. Roma: Laterza, 1973.

VIVAS, Rodrigo. O que queremos dizer quando falamos em história da arte no Brasil?

Revista Científica/FAP, Curitiba, v. 8, p. 94-114, jul./dez. 2011.

YATES, Frances. A arte da memória. Campinas: EDUNICAMP, 2007.

WARBURG, Aby. Atlas mnemosyne. Madrid: Akal, 2010.

Recebido em 23/07/2018 Aprovado em 08/06/2019

Universidade do Estado de Santa Catarina - UDESC

Programa de Pós-Graduação em História - PPGH

Revista Tempo e Argumento Volume 11 - Número 28 - Ano 2019 tempoeargumento@gmail.com 